\title{
Fıkıh Âlimleri Tarafından Telif Edilen Cedel Eserlerinde Soru Sorma ve Cevap Verme Yöntemi
}

\section{Methods of Asking and Answering Questions in Jadal Works Written by Fiqh Scholars}

\author{
Abdurrahim Bilik ${ }^{1}$ (c)
}

'Sorumlu yazar/Corresponding author: Abdurrahim Bilik (Dr.),

Trakya Üniversitesi, Illahiyat Fakültesi,

İslam Hukuku Anabilim Dalı, Edirne, Türkiye E-posta: abdurrahimbilik@hotmail.com

ORCID: 0000-0001-5442-0455

Bașvuru/Submitted: 03.06 .202

Revizyon Talebi/Revision Requested: 02.07.2021

Son Revizyon/Last Revision Received:

09.08.2021

Kabul/Accepted: 10.08.2021

Atıf/Citation: Bilik, Abdurrahim Fıkıh Âlimler Tarafından Telif Edilen Cedel Eserlerinde Soru Sorma ve Cevap Verme Yöntemi. Islam Tetkikleri Dergisi-Journal of Islamic Review 11/2,

(Eylül 2021): 569-601.

https://doi.org/10.26650/iuitd.2021.947392

\section{öz}

Peygamber Efendimizin (sav) irtihalinden sonra Müslümanlar karşılaştıkları meselelerde İslam'ın hükmünün ne olduğunu araştırmaya başlamış ve bunun sonucunda İslam'ın temel kaynaklarına nasıl yaklaşılacağı konusunda farklı yöntemler ortaya çıkmıştır. Farklı görüş sahipleri, kendi ulaştıkları sonuçları birçok açıdan teste tabi tutma ve diğer görüşler ile karşılaştırma ihtiyacı hissetmiş ve bunun sonucunda sıklıkla münazaralar gerçekleştirilmiştir. Bu münazaralar aracılığı ile hem hakikate ulaşmak için takip edilmesi gereken ilmî araştırma adımları ortaya konulmuş hem de ihtilaf edilen meselelerde bir görüş diğer görüş müntesipleri tarafından eleştiriye tabi tutularak sınanma imkânına kavuşmuştur. Münazaralarda hakikatin ortaya çıkarılabilmesi için uyulması gereken yöntemleri ele alan cedel alanında, hicri IV. asırdan itibaren fıkıh âlimleri eserler telif etmeye başlamıştır. Bu eserlerin bariz özelliği, ilmî bir araştırmanın nasıl gerçekleşmesi gerektiğinin yöntemini fıkhî örnekler üzerinden ortaya koyması ve farz ve bina gibi bazı ıstılahları açıklaması olmuştur. Bu makalede fıkı âlimleri tarafından kaleme alınan cedel eserlerinin temel bölümlerinden birini oluşturan soru sorma ve cevap verme âdabı, öne çıkan eserler üzerinden ortaya konulmaya ve ilgili ıstılahlar açıklanmaya çalışılacaktır. Böylelikle hem ilmî araştırmalarda hem de münazaralarda uyulması gereken temel ilkelerin bir kısmının ortaya konulması amaçlanmaktadır.

Anahtar Kelimeler: Fıkıh, Cedel, Münazara, Soru, Cevap, Farz, Bina

\section{ABSTRACT}

After the death of the Prophet, Muslims began to investigate the legal rulings of Islam and apply them to the legal issues they faced. Consequently, different methods have emerged about how to approach the Qur'an and the Sunna, the main sources of Islam and Islamic tradition, and various views have emerged about the issues encountered. Exponents of these different views saw the need to test their conclusions in many contexts and compare them with other viewpoints. As a result, debates were held frequently on disputed issues, especially in the fields of Theology and Fiqh. These debates allowed both the systematic research steps to be followed to reach the truth 
to be revealed and opinions on disputed issues to be criticized and tested by the advocates of other views. Jadal works, which deal with the methods required to reveal the truth in debates also came to be seen as important by figh scholars and from the hijri fourth century onwards, they began to compile works in this field. The obvious feature of these works is that they provide information on the manners and methods for carrying out debates and systematic research on controversial figh issues through legal examples while explaining some terms such as fard and binā'. In this article, the methods for asking and answering questions, which constitute one of the basic elements of the works of jadal written by figh scholars, will be examined through various prominent works, and the relevant terms will be explained. This study aims to reveal some of the basic principles that should be followed in systematic research and in debates among scholars using the question and answer method adopted by the fiqh scholars who compiled most jadal works.

Keywords: Fiqh, Jadal, Debates, Questions, Answers, Fard, Binā'

\section{EXTENDED ABSTRACT}

After the death of the Prophet, Muslims began to investigate the existing legal rulings of Islam and apply them to the new legal issues they faced. As this process developed, different methods emerged about how to approach the Qur'an and the Sunna, the main sources of Islam. Different views have emerged about the issues encountered. Proponents of these different views saw the need to test their conclusions in many respects and compare them with other views. As a result, debates were frequently held on disputed issues, especially in the fields of Theology and Fiqh. These debates allowed both the systematic research steps to be followed to reach the truth, to be revealed, and opinions on disputed issues to be criticized and tested by the advocates of other opinions. Jadal works, which deal with the methods that should be followed to reveal the truth in debates, began to be seen as important by fiqh scholars at the same time. From the hijri fourth century onward, these scholars began to compile works in this field. The most prominent feature of these works is that they provide information on the manners and methods of carrying out debates and scientific research on controversial fiqh issues through legal examples while explaining some terms such as fard and bina $\bar{a}^{\text {. }}$.

In this article, the author will reveal the manner of asking and answering questions, which constitutes one of the central facets of the works of jadal written by fiqh scholars, through the notable works of such scholars and the relevant terms explained. This study aims to reveal some of the basic principles that should be followed both in scientific research and in debates between scholars through the question and answer method developed by fiqh scholars.

In order to achieve this aim, this paper will first consider the where of the question and answer method mentioned in the works of Jadal. It will examine works compiled by the fiqh scholars that revealed the method. It will be demonstrated that the question and the answer, together with relevant evidences and objections, were the main subjects of Jadal.

In these Jadal works, the related concepts/terms are explained first, and then the questionanswer method is put forward. In addition, in some Jadal works, the basic Interrogatives are explained as similar to those in logic works. Finally, under the heading of evidences and objections, the works illustrate how the method can be adapted to the fiqh proofs through examples.

Later in this article, Shirazi and Bacî were taken to the center and what the parts of the question were and which questions should be asked in what order were revealed. 
Accordingly, the questions that needed to be asked in discussions were as follows: asking whether the person being questioned had an opinion on the relevant issue; asking, if so, the nature of the opinion; asking for the evidence supporting the opinion; asking how the relevant evidence explains the relevant opinion; and testing the accuracy of the evidence by questioning the aspects of the evidence that are more likely to be criticized.

The last question to be considered is the accuracy of the evidence by asking the following questions: questions asked to test whether the evidence is presented correctly and completely, questions regarding the aspects of the evidence thought to be wrong, questions about how the evidence can be reconciled with the basic principles believed to be contradictory, questions asked with the claim that the respondent is inconsistent in handling the evidence put forward by the respondent, and finally, questions about how to explain the evidence presented by the claimant. The different evidence supporting different claims is listed. For any item of evidence to be accepted as true, it must be able to produce answers to these basic questions.

Later in this article, possible mistakes emerged in the questions revealed based on Ghazali's relevant explanations. Accordingly, the errors in any given question may be caused by one or more of the following: the person asking the question, the question itself, the person being questioned, and the subject sought to be understood. Based on these, the issue considered in the discussion should not be one of the commonly known topics. Nor should the question be asked ambiguously or in combination with other issues. The person to whom the question is addressed should be competent to respond to the relevant issue, and the question asked should not be one of the issues that cannot be known.

After discussing the subjects of questions and answers, two issues that are particularly

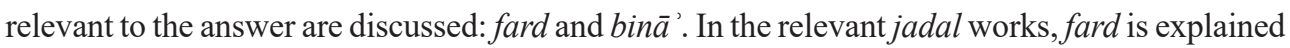
as meaning answering a general question by explaining only one of the issues covered by the question, or as presenting evidence for only one of the issues covered by the answer after giving a general answer. The question of whether it is legitimate to make a fard while answering was in the works of Jadal, and different answers have been put forward. Bina ', which also means to explain an issue from the basis of procedural principles or from another issue, is used to explain the other issues covered by the question aside from the specific answer or specific evidence after giving a specific answer regarding the fard in the relevant Jadal works. In the answer, different opinions have been put forward based on different reasoning regarding whether it is necessary for the person who makes the "fard" to make "bina " " or not.

The question-answer methods explained in Jadal's works not only reveal the rules of how systematic debates should be conducted, but also contain rules that should be taken into account to reach correct conclusions about aspects of the issue examined during systematic research and how to test the answers found. In this respect, it is possible to say that the principles and methods explained in the works of Jadal should be taken into account, especially in research methods in the field of social sciences.

On the other hand, it is absolutely necessary to know the rules laid down in the works of Jadal in order to understand the works compiled in the field of ilmu'l-khilaf and the relevant references to the concept of jadal in the works of Fiqh and the Theology. 


\section{Giriş}

Birçok ayet ve hadiste Müslümanlar ilme yönlendirilmiş, kendi konumunun gerektirdiği ilmi öğrenmenin her Müslümana farz olduğu belirtilmiş, ${ }^{1}$ ilim öğrenmek için çabalayanlar müjdelenmiştir. ${ }^{2}$ Hiç şüphesiz ilim öğrenmenin; okumak, dinlemek, gözlemlemek, tecrübe etmek ve tefekkür etmek gibi birçok yolu vardır ve soru sormak da ilim öğrenmeyi sağlayan yöntemlerden biridir. Bu özelliğinin yanında soru sormak, farklı öğrenme yöntemleri vesilesi ile kişilerin elde ettiği bilgilerde anlayamadıkları veya şüpheye düştükleri konuları anlamalarını ve şüphelerini gidermeyi ve farklı görüşler arasında mukayese yapabilme imkânını sağlamaktadır.

Kuran-1 Kerim'de, "Eğer bilmiyorsanız zikir ehline (Ehl-i Kitab'a, ilim sahiplerine) sorun" (Enbiya, 21/7) ve "Senden önce gönderdiğimiz elçilere sor; Biz, Rahman olan Allah'tan başka kulluk edilecek ilahlar var etmiş miyiz?" (Zuhruf, 43/45) ayetleri ile bilmedikleri konularda Müslümanlar bilenlere sorarak öğrenmeye yönlendirilmiştir. Peygamber Efendimiz'den (sav) ve İslam büyüklerinden aktarılan birçok rivayet ile Müslümanlar bilmedikleri konularda sormaya yönlendirilmiştir. Bu rivayetlerden bir kısmı şöyledir: "Bir sefere çıkmıştık, bizden bir adama taş değdi ve başını yardı. Sonra bu zat ihtilam oldu. Arkadaşlarına: 'Benim teyemmüm etmeme ruhsat var mı?' diye sordu. 'Sen suyu kullanabilirsin, sana (teyemmüm için) ruhsat bulmuyoruz.' dediler. Adam yıkandı, akabinde de öldü. Peygamberin huzuruna geldiğimizde bu hâdise (kendisine) haber verildi. Bunun üzerine Rasûlullah: '(Fetvayı verenler) onu öldürdüler, Allah da onları öldürsün. Bilmediklerini sorsalardı ya! Cehaletin ilacı ancak sormaktır. Onun teyemmüm etmesi, yarasının üzerine bir bez bağlayıp sonra üzerine meshetmesi ve vücudunun geri kalan kısmını da yıkaması ona yeterdi.' diye buyurdu." "3 "İlim bir hazinedir, anahtarı soru sormaktır." "Güzel soru sormak, ilmin yarısıdır."4 el-Hatib el-Bağdadî (ö. 463/1072) Ebu Hanife için özetle şöyle demektedir: "Hiç şüphesiz Ebu Hanife meseleleri (mesail) ilk kez ortaya koyan kişidir. Peygamber Efendimiz güzel soru sormak ilmin yarısıdır buyurmuştur. Ebu Hanife, ilmin yarısını soru sorarak elde etmiştir. Sonra bu sorulara cevap vermiş ve böylelikle ilmin yarısını da cevap vererek elde etmiştir." İbn Hacer el-Askalanî (ö. 852/1449), ilmin soru ve cevaptan ibaret olduğunu ifade etmiştir. ${ }^{6}$ Muhammed Abdurrauf el-Münavî (ö. 1031/1622) güzel soru sormanın ilmin yarısı olduğunu ve bunun dinî konularda olduğu gibi dünyevî konularda da övgüye değer olduğunu ifade etmiştir.?

1 Peygamber Efendimiz (sav) "İlim talep etmek her Müslüman erkek ve kadın üzerine farzdır

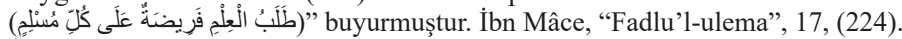

2 Örnek olarak Kuran-1 Kerim'de "De ki: Hiç bilenlerle bilmeyenler bir olur mu?” (Zümer, 39/9.) buyurularak ilim sahibi olanların faziletine işaret edilmiştir.

3 Ebu Davud, "el-Mecruh Yeteyemmemu" (336).

4 Her iki cümle için bkz. Ebü'l-Hasen Alî b. Muhammed b. Habîb el-Basrî el-Mâverdî, Edebü'd-dünya ve'd-din, (yy: Daru Mektebetü'l-Hayat, ty), 70.

5 Hatib el-Bağdadî, Tarihu Bağdat, thk. Doktor Beşşar Avad, (Beyrut: Daru'l-Garbi'1-İslamî, 2020/1422), XXII, 98.

6 İbn Hacer el-Askalanî, Fethu'l-barî şerhu Sahihi'l-Buharî, (Beyrut: Daru'l-Marife, 1379), I, 142.

7 Muhammed Abdurrauf el-Münavî, Feyzu 'l-kadir şerhu'l-Camiu's-sağir, (Misır: el-Mektebetü't-Ticariyeti'l-Kübra, 1356), III, 575. Buraya kadar anlatılan soru sormanın cedel ilminde yer alan soru sormaktan farklı olduğu, zira cedel ilminde sorularını hasmı ilzam etmek için serdedildiği iddia edilebilir olsa da, cedel eserlerinde amacın ilzamu'l-hasm değil de izharu'l-hak olması gerektiği şeklindeki güçlü vurgu sebebiyle, yukarıdaki ifadelerle cedel ilminde yer alan sorular arasında bağlantı kurulmuştur. Cedel eserlerinde izharu'l-hak vurgusu için bkz. Abdurrahim Bilik, Fikhın Bir Alt Disiplini Olarak Ilmu 'l-Hilaf, (İstanbul: Marmara Üniversitesi, Sosyal Bilimler Enstitüsü, Doktora Tezi, 2018), 159-168. 
İlim öğrenmenin öneminin ve gerekliliğinin bilincinde olan birçok İslam âlimi, kendi ulaştığ1 veya benimsediği sonuçları münazara aracılığı ile test etmek istemiş ve böylelikle hakikate ulaşabilmeyi amaçlamışlardır. Nitekim cedel ilminin yöntemleri, gerek kişinin bir başına düşünmesi gerek iki taraf arasında münazara cereyan etmesi bakımından bilgiye ulaşmada ve ulaşılan bilginin sınanmasında bir mahkeme salonunda davalı ve davacının iddia edilen hak konusunda kıyasıya mücadele etmelerine benzetilmiştir. ${ }^{8}$ İslam ilim geleneğinde münazara, özellikle kelam ve fikıh gibi alanlarda yaygınlaşmış ${ }^{9}$ ve İslamî ilimler eğitiminde belirleyici bir rol üstlenmiştir. Süreç içerisinde ilmî meselelerde bilgiye ulaştıran karşılıklı konuşma ve düşünmenin kurallarının belirlenmesi ihtiyacı hâsıl olmuş ve bu amaçla cedel eserleri kaleme alınmıştır. Fıkıh âlimleri de, fıkıh alanında sıklıkla gerçekleşen münazaranın kaidelerini belirleyen cedel eserleri yazımına kayıtsız kalmamış ve el-Kaffal eş-Şaşî (ö. 365/976) ile başlayan bir süreçte bu alanda çok değerli eserler telif etmişlerdir. ${ }^{10} \mathrm{Bu}$ eserlerde bir yandan hakikate ulaşabilmek ve ilmi konularda sağlıklı biçimde karşılıklı konuşabilmek ve düşünebilmek için riayet edilmesi gerekli görülen kurallar ortaya konulmuş, bir yandan da ihtilaf edilen fikhî meselelerde ${ }^{11}$ bu ilkelerin nasıl işletileceği/uygulanacağı ele alınmıştır.

8 Zerkeşî kıyas delili üzerinden bu benzetmeyi özetle şöyle ortaya koymaktadır: "Bazıları; şer'î hükmü araştırma

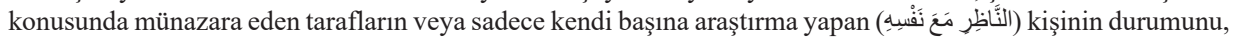
hâkim karşısındaki iki hasmın durumuna benzetmişlerdir. Buna göre: müstedil müddei (davacı) konumunda, sail müddea aleyh (davalı) konumunda, araştırılan hüküm iddia edilen hak konumundadır. Kıyastaki asıl, mahkemedeki şahitler gibidir. Aslın illeti, şahidin şahitlik yapmak suretiyle konuşması gibidir. Şeriat yani Kitap ve Sünnet, iddiaları veya savunmaları tasdik ederek veya reddederek hükmü uygulamaya veya uygulamamaya karar veren hâkim konumundadır. Farklı ihtimallerin (nazar) varlığından ötürü sailin kıyası reddetmesi, şahitlerin tezyif edilmesi ve lazım bir durumdan ötürü reddedilmeleri gibidir. Aslın hükmünde ve vasfında mümanaat, şahitlerin varlığını inkâr etmek gibidir. Asıldaki illetin varlığında mümanaat, şahitlerin şehadetlerini inkâr etmek gibidir. Keza fer'de illetin varlığını inkâr etmek de bunun gibidir. Fasid vaz', şehadetlerin birbirini nefyetmesi ve muvafakat etmeleri gibidir. İlletin sahihliğine dair delil mutalebe etmek, davacıyı şahitlerin adaletini ispatlaması ile sorumlu kılmak gibidir. Nakz, şahitlik ettikleri durumun benzerinde şahitlerin yalancı çıkmaları gibidir. Delilin gerektirdiğini söylemek (el-kavlu bi'l-mucib), davacının iddiasını ortaya koyduğuna dair her hangi bir şüphe kalmaması için şehadeti, içerdiği muhtemel anlamlar ile açıklamak gibidir. Muaraza, şahitler karşısına şahitlerin iddialarının aksini gösteren beyyine ortaya koymak gibidir ki bu durumda iki şehadet (şahitlerin ve beyyinenin şehadetleri) birbirini çürütürler. Bunların hepsi kıyası ifsad eder. Bir kıyas bunların hepsinden sağlam olarak çıkarsa o zaman kendisiyle amel edilebilir." Zerkeşî, el-Bahru'l-muhit fi usuli'l-fikh, VII, 436.

9 Kelam alanında cedel kullanımı konusunda bk. Hüseyin Doğan, "İslam Kelamcılarına göre cedel yönteminin uygulama alanı ve pratikteki yansımaları”, Kafkas Üniversitesi Illahiyat Fakültesi Dergisi, 4/7 (2017), 67-96; Hikmet Yağlı Mavil, “Ebü'l-Hasan el-Eş’arî’nin Kelam Sisteminde Bir Bilgi Kaynağı Olarak Cedel”, Kelam Araştırmaları Dergisi, 10/2 (2012), 175-186. Fıkıh alanında cedel kullanımı hususunda bk. Şükrü Özen, "İlm-i Hilaf yahut Fukaha Metoduna Göre Cedel Hakkında Klasik Bir Metin: Menşeü’n-Nazar”, Makalat, 2, (1999), 171-198; Ahmet Numan Ünver, Fıkıh İlminde Cedel Yönteminin Kullanımı (Ebû İshâk eş-Şîrâzî Örneği), (Ankara: Akademisyen Kitabevi, 2019); Ahmet Numan Ünver, "Cedelin F1kıh İlminde Kullanımı: Kudurî ve Ebu’t-Tayyib et-Taberî Arasındaki Bir Münazara Bağlamaında”, Sakarya Üniversitesi İlahiyat Fakültesi Dergisi, 21/39,(2019), 68-91; Bilik, Flkhın Bir Alt Disiplini Olarak İlmu'l-Hilaf, 170-228.

10 F1kıh âlimlerinin cedel eserleri telif etmeye başlamasının ilk örneğinin el-Kaffal eş-Şaşî olduğu konusunda bk. Ebu İshak İbrahim b. Ali eş-Șirazî, Tabakatu'l-fukaha, nșr. İhsan Abbas, Beyrut: (Daru'r-Raidi'l-Arabî, 1970), 112; George Makdisî, Ortaçağda Yüksek Öğretim, çev. Ali Hakan Çavuşoğlu, Tuncay Başoğlu, (İstanbul: Klasik Yayınları 2012), 224.

11 Bir konuda münazara yapılabilmesi için o konunun, hakkında ihtilaf edilen bir konu olması gerekmektedir. İttifak edilen konularda münazara yapılamayacağı cedel eserlerinde belirtilmiştir. Bk. Ebu'l-Vefa İbn Akil, el-Vazıh $f i$ usuli'l-fikh, thk. Abdullah b. Abdülmuhsin et-Türki, (Beyrut: Müessesetü’r-Risâle, 1999/1420), I, 309. 
Bu çalışmada fikıh âlimlerinin telif ettiği öne çıkan cedel eserlerinde soru sorma ve cevap verme yöntemlerini nasıl belirledikleri ve fikı meselelerine nasıl uyarladıkları ortaya konulmaya çalışılacaktır. ${ }^{12}$ Böylelikle bu zengin birikimin günümüz ilmî konuşmalarına, araştırmalarına ve akıl yürütmelerine de 1şık tutması hedeflenmektedir. Çalışma boyunca ilgili başlıklar altında konular ele alınırken cedel müelliflerinin söz konusu görüşleri kronolojik olarak sıralanmayacak, o başlık altında ele alınan konuyu en ayrıntılı olarak açıklayan cedel müellifi merkeze alınacaktır. Böylelikle hem karşılıklı olarak ilmî bir konunun nasıl ele alınması gerektiğinin hem de bireysel araştırmalarda araştırma sorularının ve elde edilmek istenilen cevapların hangi özelliklere sahip olması gerektiğinin daha iyi ortaya konulması ve ilgili konularda muhtasar ve kapalı lafızlar kullanan cedel müelliflerinin ifadelerinin daha iyi anlaşılabilmesi amaçlanmıştır.

\section{Cedel ilminde soru ve cevabın yeri}

Cedelin rükünlerinin nasıl taksim edileceği ve kaç tane olduğu konusunda farklı yaklaşımlar olmakla beraber, cedel müelliflerinin çoğu sorular ve cevaplara cedelin rükünleri olarak yer vermektedir. Bundan hareketle önce cedelin rükünleri konusunda kısaca bilgi verilecektir. Necmuddin et-Tufî’nin (ö. 716/1316) belirttiği üzere rüknün iki anlamı vardır: 1. Tıpkı rükû ve secdenin namazın rükünleri oluşu gibi, o şeyin hakikatinin bir parçası anlamındadır. 2. Bir şeyin tahakkuku kendisine bağlı olan anlamındadır ki bu, rüknün ilk anlamından daha umumidir. Tufî’ye göre rüknün ikinci anlamı açısından cedelin rükünleri şunlardır: A. ed-Dâl,

12 Çağdaş literatür arasında ilgili konuyu ele alan çalışmalardan bazıları kısaca şöyledir: Larry Benjamin Miller, Islamic Disputation Theory: The Uses-Rules of Argument in Medieval Islam, (Springer, 2019). Miller beş temel başlıktan oluşturduğu çalışmasında dördüncü başlıkta İslam Hukukunda cedel yöntemini Cüveynî, Bacî ve İbn Akil'i merkeze alarak incelemektedir (49-62). Walter Edward Young, The Dialectical Forge: Juridical Disputation and the Evoluatin of Islamic Law, (Springer, 2017). Young, dokuz temel başlıktan oluşturduğu bu çalışmasının cedel sistemini açıkladığı dördüncü başlığında alt bir başlık olarak soru ve cevap kısımlarını Şirazî ve Bacî’yi merkeze alarak ve tablolaştırarak incelemektedir (129-137). Miller ve Young, söz konusu eserlerinde tartışma yöntemini sembolik mantığın dili ile ifade etmeye çalışarak konuyu daha genel bir bakış açısı ile sunmaya da çalışmışlardır. Ahmet Numan Ünver, Fıkıh İlminde Cedel Yönteminin Kullanımı (Ebû İshâk eş-Şîrâzî Örneği), Ankara: Akademisyen Kitabevi, 2019. Ünver, üç bölümden oluşturduğu çalışmasının ikinci bölümünün sonunda Şirazî’ye göre cedelde soru ve cevapların nasıl olması gerektiği konusunu ele almaktadır (117-139). Ünver, ilgili konuyu ele alırken yeri geldikçe diğer cedel ve fikıh usulü eserlerine de gönderme yapmaktadır. Görüldüğü üzere konuyu ele alan çalışmalar Şirazî ve onun cedel üzerine çalışmalarını Malikî mezhebine uyarlayan öğrencisi Bacî’yi merkeze almaktadırlar. Bu durumu, söz konusu müelliflerin hem kendilerinden sonraki ilgili çalışmaları etkilemesi hem de cedeli fikıh açısından ele alan en kapsamlı ve açık eserlerden ikisi olması ile açıklamak mümkündür. Bu çalışmada Cüveynî, Şirazî, Bacî, Gazalî, İbn Akil, Razî ve Tufî gibi cedel müelliflerinin sorucevap yöntemi konusundaki yaklaşımları, her başlığı en iyi açıkladığını düşündüğümüz müellif merkeze alınarak açıklanmaya çalışılacaktır. Ayrıca soru-cevap yöntemi açısından önemli başlıklar olan farz ve bina yöntemleri de bu çalışmada daha kapsamlı bir biçimce ortaya konulmaya çalışılacaktır. Böylelikle soru-cevap yöntemi konusunda daha kapsamlı bir bakış açısı sunmak ve bu konuyu ele alan Türkçe literatüre mütevazı bir katkı sunmak hedeflenmektedir. 
B. ed-Delil, C. el-Müstedil, D. el-Müstedellü aleyh, E. el-Müstedellü leh. ${ }^{13}$

$\mathrm{O}$ şeyin hakikatinin bir parçası anlamında cedelin rükünlerinin neler olduğu hususunda iki farklı görüş öne sürülmüştür:

1. Cedelin rükünlerini ayrıntılı olarak ortaya koyan bu yaklaşıma göre cedelin dört veya beş rüknü vardır: Örnek olarak Tufî; soru, cevap, istidlal, itiraz ve itirazdan kurtulma yöntemi olmak üzere cedelin beş rüknünün olduğunu ifade etmektedir. ${ }^{14}$ Fahreddin er-Razî (ö. 606/1210) bunlardan sadece ilk dördünü zikrederek cedelin rükünlerinin sorular, cevaplar, deliller ve itirazlar olduğunu belirtmektedir. Razî, diğer konuların bunlardan birine tabi olduğunu ifade etmektedir. $^{15}$

2. Cedelin rükünleri sadece soru ve cevap olmak üzere iki tanedir. Çünkü deliller ve itirazlar, soru ve cevabın kapsamına dâhildir. ${ }^{16}$ Mesela Şirazî (ö. 476/1083), cedelin tümünün soru ve cevaptan oluştuğunu söylemektedir. ${ }^{17}$

İlk görüş, aslında fukaha tarafından kaleme alınan cedel eserlerinin temel bölümlerini de yansitmaktadır. Zira bu cedel eserlerinin genel olarak mukaddime ve ilgili istılahların tanıtımı dışında iki temel bölüm çerçevesinde kaleme alındığını söylemek mümkündür. Bu bölümlerden ilki "sorular ve cevaplar", diğeri ise "deliller ve itirazlar" şeklindedir. Bu rükünler dışında bir de bunlara tabi olarak zikredilen konular vardır ki onlar da delillerin, soruların ve cedelin nasıl biteceğinin tertibi hakkındadır. ${ }^{18}$ Cedelin rükünleri konusundaki ikinci görüş, deliller ve itirazların soru ve cevapların kapsamına girdiğini söylemektedir. el-Cüveynî (ö. 478/1085), soru ve cevaba bazılarının ilzamı da ekleyerek cedelin rükünlerini üçe çıkardığını, fakat ilzamın aslında sorunun kapsamına dâhil olduğunu ifade etmektedir. ${ }^{19}$

Yukarıdaki açıklamalardan da anlaşıldığı üzere, bu çalışmanın konusu olan sorular ve cevaplar, cedel ilminin temel rükünlerini oluşturmaktadır. İleride görüleceği üzere deliller ve

13 A. ed-Dâl: Delilleri ortaya koyan anlamındadır. Delilleri ortaya koyan gerçekte Allah'tır çünkü aklî, sem'î ve bu ikisinden oluşan delilleri gerçekte var edip yerleştiren Allah'tır. Bu kavram fer'î olarak, delilleri açıklayan ve tahkik eden Peygamber için ve herhangi bir konuda delil zikreden herkes için de kullanılmaktadır. B. ed-Delil: İstenilene ulaştıran manadır. Delilin "ulaştıran” şeklinde özne/fail olarak kullanılması mecazdır, çünkü aslında delillere bu özelliği veren Allah’tır. C. el-Müstedil: Delilleri bularak zikreden kişidir ki bu yolla matlubuna/ istediğine ulaşmak istemektedir. Müstedil, delilleri bulup zikretmekle ya doğruya ulaşmak ya da hasmını mağlup etmek istemektedir. D. el-Müstedellü aleyh: Delil getirilerek bulunmak istenen hüküm anlamındadır.

E. el-Müstedellü leh: Kendisi için delil getirilen anlamındadır. Münazaralarda bu, soru sorup itiraz eden kişi olabilir zira eğer karşıdaki öğrenmek istiyorsa hükmü onun için izhar etmek, eğer karşıdaki inat ediyorsa onu susturmak için istidlal yapılmaktadır. Ayrıntılı bilgi için bkz. Ebü’r-Rebî‘ Necmüddîn Süleymân b. Abdilkavî b. Abdilkerîm b. Saîd et-Tûfî el-Hanbelî, Alemü'l-cezel fi ilmi'l-cedel, thk. Heinrich Wolfhard (Wiesbaden: Franz Steiner Verlag, 1987). 19-20.

14 Tufî, Alemü'l-cezel fi ilmi'l-cedel, 19.

15 Fahreddin er-Razî, el-Kaşif, thk. Ahmed Hicâzî es-Sekkâ, (Beyrut: Dârü'l-Cil, 1992/1413), 65.

16 Cüveynî, el-Kafiye fi'l-cedel, thk. Fevkıyye Hüseyin Mahmûd, (Kahire: İsa el-Babi el-Halebi, 1979$), 72$.

17 Şirazî, el-Mülahhas, thk. Muhammed Yusuf Niyazî, (Ümmü'l-Kura Üniversitesi, Külliyetü'ş-şeri'â, Yüksek lisans tezi, h. 1407), 119. Kronolojik olarak Cüveynî ve Şirazî, Razî ve Tufî’ den daha önce olmasına rağmen burada sorular ve cevaplar ön plana çıkarılmak için konu izah edilirken söz konusu kronoloji dikkate alınmamıştır.

18 Fahreddin er-Razî, el-Kaşif, 65.

19 Cüveynî, el-Kafiye fi'l-cedel, 72. Cüveynî, cedelin rükünlerine ilzamı ekleyenlerin kimler olduğunu zikretmediği için bu görüşe, cedelin rükünleri kısmında farklı bir görüş olarak yer vermedik. 
itirazlar, esasında sorular ve cevapların birer alt başlığı olarak ele alınmakta ve münazaranın ilerleyen aşamalarında delillerin sorulacağı ve ortaya konulan delillere itiraz sorularının yönlendirileceği ifade edilmektedir. Bununla beraber, fikıh âlimleri tarafından telif edilen cedel eserlerinin çoğunda, deliller ve itirazlar konusuna sorular ve cevaplar konusundan sonra müstakil bir bölüm olarak yer verilmekte ve bu bölüm altında edille-i şer'iyye'nin her biri (kitap, sünnet, icma, kıyas vs.), söz konusu delillerin cedel kaideleri doğrultusunda nasıl sınanacağı açıklanarak müstakil birer alt başlık halinde ele alınmaktadır.

\section{Soru (sual) ve cevap kelimelerinin anlamları ve temel soru edatları}

Kelime olarak soru (sual), istemek ve talep etmek anlamına gelmektedir. Sorunun kullanımlarından hareketle farklı kısımlara bölünmesi mümkündür. Bunlar kısaca hal-hatır soruları, öğrencinin hocadan öğrenmek için soruları, inat ve karşıdakini aciz bırakma soruları şeklinde özetlenebilir. ${ }^{20}$ Cedel eserlerinde soru farklı şekillerde tarif edilmiştir. Cüveynî, "soru, yönlendirmek (istid'a') anlamına gelmektedir. Talep anlamına geldiği de, karşıdakini cevap vermeye yönlendirmek anlamına geldiği de söylenmiştir” demektedir. ${ }^{21}$ Razî, sorunun (sual) kelime olarak talep etmek/istemek anlamına geldiğini belirttikten sonra şöyle demektedir:

Bu istemek, ĕger karşıdakinin konuşmasını/açıklamasını istemek ise bu, karşıdakinden bilgilendirmesini istemek (isti'lam) ve haber vermesini istemek (istihbar) anlamina gelmektedir. Eğer karşıdakinin bir davranışta bulunmasını istemek ise bu, dua ve yardım dilemek anlamına gelmektedir. İlk tür sorunun cevabı, bilmek isteyen kişiye bildirmektir (i lam). İkinci tür sorunun cevabı ise sıkıntıda olan kişiye yardım etmektir. ${ }^{22}$

Ebü'l-Vefa İbn Akil (ö. 513/1119), cedel 1stılahında sorunun farklı bir anlama geldiğini iddia etmektedir. Ona göre cedel istılahında soru, "deliller yoluyla hasmın mezhebini değiştirmeyi istemek" anlamına gelmektedir. ${ }^{23}$ Cedel eserlerinde genel olarak münazaraların hasmı mağlup etmek amacıyla değil, hakkı ortaya çıkarmak amacıyla yapılması gerektiğinin vurgulandığı göz önüne alındığında cedele dair bu tür tariflerin münazarada bu amaçtan sapan kişiler için yapıldığını söylemek mümkündür. Diğer bir deyişle "hakkı izhar etmek" amacı merkeze alınarak yapılan tarifler cedel teorisinden hareketle yapılmışken, "hasmı ilzam etmek" amacı merkeze alınarak yapılan tarifler ise cedel pratiğinden hareketle yapılmıştır denilebilir. Bu tarif için bir başka ihtimal de şöyledir: İbn Akil, herkes kendi mezhebini hak olarak gördüğünden münazarada karşı tarafın mezhebini değiştirmeyi sağlamayı, tarafların karşı tarafı hakikate çevirmek olarak gördüğünü kast etmiş olabilir. Nitekim cedelin amacını açıklarken bazılarının cedelin amacının cedel aracılığı ile hakka isabet etmek olarak gördüklerini söyleyip itiraz

20 Ebü’r-Rebî‘ Necmüddîn Süleymân b. Abdilkavî b. Abdilkerîm b. Saîd et-Tûfî el-Hanbelî, Şerhu Muhtarari’rRavza, thk. Abdullah b. Abdulmuhsin et-Türkî, (Beyrut: Müessestür'r-Risale, 1987), III, 458-459; Mes'ud b. Musa Fülusi, el-Cedel inde'l-usuliyyin beyne'n-nazariyye ve't-tatbik, (Riyad: Mektebetü'r-Rüşd, 2003/1424), 230.

21 Cüveynî, el-Kafiye fi'l-cedel, 69

22 Fahreddin er-Razî, el-Kaşif, 66.

23 İbn Akil, el-Vazıh fi usuli'l-fikh, I, 298; Fülusi, el-Cedel inde'l-usuliyyin, 231. 
etmektedir. Ona göre bu, nazarın amacıdır zira nazar aracılığı ile kişi hakka isabet etmektedir. Fakat cedelde tarafların her biri, diğer tarafı batıldan (kendi ulaştığını düşündüğü) hakka ve yanlıştan (kendi inandığı) doğruya çevirmek istemektedir. ${ }^{24}$ Bundan hareketle o, cedel sorularının diğer sorularda aranmayan bazı şartları haiz olması gerektiğini söylemektedir. ${ }^{25}$ İbn Akil; soru (sual), isti'lam, istihbar ve isifham kelimelerinin benzer olduğunu fakat aralarında şöyle farklar olduğunu söylemektedir: istihbar haber talep etmek, isti'lam ilim talep etmek ve istifham da anlamayı/fehm etmeyi talep etmektir. ${ }^{26}$

Cevap, kelime olarak kesmek anlamına gelmektedir. Soruya uygun olarak verilen karşılığa 1stılah olarak cevap denilmiştir çünkü verilen bu karşılıkla ihtimallerin önü kesilmiş olur. Mesela “Zeyd geldi mi?" sorusunu soran kişinin zihninde iki ihtimal vardır: Zeyd gelmiş olabilir veya gelmemiş olabilir. Cevap veren kişi verdiği cevapla bu ihtimalleri kesin bir sonuca bağlamakta ve böylelikle ihtimallerin önünü kesmiş olmaktadır. ${ }^{27}$

Bir konunun hem nasıl araştırılacağını ortaya koymak hem de cevabın soruya uygun olmasını sağlamak amacıyla, soru edatları ve her soru edatı karşısında nasıl cevap verilmesi gerektiği cedel eserlerinde açıklanmıştır. Temel soru edatlarının neler olduğu, dolayısıyla bir konuyu araştırıp öğrenmek için hangi soruların temel olarak sorulması gerektiğine dair cedel eserlerinde farkı yaklaşımlar ortaya konulmuştur. İbn Akil, soru edatlarının on tane olduğunu belirtirken, İbn Hazm (ö. 456/1064), el-Gazalî (ö. 505/1111) ve Fahrettin er-Razî dört soru edatı ortaya koymuşlar ve diğer soru edatlarının saydıkları dört temel sorunun altında değerlendirilebileceğini ifade etmişlerdir. Bununla beraber aynı soru edatlarını zikreden Gazalî ve Razî’nin dört temel sorunun sıralamasında farklı yaklaşımlar ortaya koydukları görülmektedir.

İbn Akil'in kullanımlarından örnekler vererek açıkladığı ve cevaplarının nasıl olması

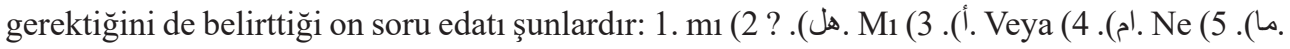

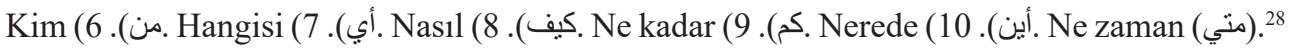

Razî, ilim öğrenmek için yapılacak araştırmaların belirli bir aşaması ve her aşamanın da kendine has bir soru kalıbı olduğunu belirttikten sonra bu aşamaları ve soru kalıplarını özetle şöyle açıklamaktadır:

1. Araştırmanın ilk aşaması olarak, malum olan bir şeyin varlığını ya da yokluğunu öğrenmek yer almaktadır. Bu aşamada soru kalıbı "mı? ("هل" ve "“")" şeklindedir. Bu soru mutlak ve mukayyed olmak üzere iki kısma ayrılmaktadır: A. Mutlak: Bir şeyin başlı başına var olup olmadığını öğrenmek için sorulan sorudur. Mesela "bu şey mevcut mudur?” sorusu. B. Mukayyed: Var olan şeyin bir halini öğrenmek için sorulan soru. Mesela "Zeyd âlim midir?" yani “O, âlim olarak mı mevcuttur?" sorusu.

24 İbn Akil, el-Vazıh fi usuli' '-fikh, I, 297; Burada yer alan nazar ifadesinin cedel açısından da bilgiye veya zann-1 galibe erişebilmek amacıyla tefekkür etmek veya bilgiye veya zann- galibe erişebilmek için akla uygun olarak önceki inanç, bilgi ve zanları tertip etmek anlamında geldiği unutulmamalı, bu ifade münazara kavramı ile karıştırılmamalıdır. Nazar ifadesinin anlamı için bkz. Razî, el-Kaşif, 20.

28 İbn Akil, el-Vazıh fi usuli' '-fikh, I, 298-300. 
2. Araştırmanın ikinci aşaması olarak, var olduğu bilinen bir şeyin hakikatini ve varlığının sıhhatini öğrenmek yer almaktadır. Bu sorunun kalıbı "nedir (ما)" şeklindedir. Mesela "insanın hakikati nedir?", "meleğin/melikin hakikati nedir?" soruları gibi. Bu soru bazen hakikati öğrenmek için bazen de resm ${ }^{29}$ ve temyizi (araştırılan konuyu benzerlerinden ayırmayı) öğrenmek için sorulur.

3. Araştırmanın üçüncü aşaması olarak, umumi bir durumda o şeyin zatında olan veya o şeye arız olan, kendisinden ayrılmayan veya kendisinde bulunması sahih olan bir özellikten hareketle, bilinen şeyi benzerlerinden ayırt etmek (temyiz) yer almaktadır. Bu aşamada sorunun kalıbı "hangi (اي)" şeklindedir. Mesela: "bu hangi canlıdır?", "bu hangi renktir?" soruları gibi. Aynı şekilde hakikatlerin taksim edilmesini gerektiren tüm vasıflar -ister zatî ister arızî olsun- bu sorunun kapsamına girmektedir. Zatî bir özellik sorulmuş ise zatî bir fasıl ile cevap verilir, arızî vasfa dair soru sorulmuşsa ayırıcı olan arızî vasıflarla cevap verilir. 4. Araştırmanın dördüncü aşaması olarak, ta'lil edilmesi sahih olanlar için, varlığı sabit olanın illetini öğrenmek yer almaktadır. Bu aşamada sorunun kalıbı "niçin (لم)" sorusudur. Bu soru kalıbı iki yerde kullanılmaktadır: A. Var olan bir şeyin varlığının illetini öğrenmek için kullanılır. Bu sorunun cevabı müessir illetin kıyası ile verilir. B. Var olduğuna inanılan şeyin illetini öğrenmek için kullanılır. Bu sorunun cevabı delalet kıyası ile verilir. ${ }^{30}$

İbn Hazm, bu dört soruyu "mı”, "ne”, "nasıl” ve "niçin” şeklinde vermektedir. ${ }^{31}$ Gazalî, bu dört temel soruyu; “mı”, "ne”, "niçin” ve "hangi” sıralaması ile vermektedir. ${ }^{32}$ Razî’nin Gazalî’den farklı olarak bu sıralamada "hangi” sorusunu üçüncü olarak zikrettiği, "niçin” sorusunu ise sona bıraktığı görülmektedir. Hem Gazalî hem Razî, dörtlü sıralamayı ve soru kalıplarını verdikten sonra temel soruların bunlardan ibaret olduğunu ve diğer soruların bu dört temel sorudan birinin altında değerlendirileceğini ifade etmektedirler. Buna göre "nerede", "ne zaman" ve "nasıl” soruları, mukayyet şeklinde sorulduğunda "mı" sorusunun kapsamına dâhildir. "Kim", "dı̆̆ında", ve "her olduğunda" gibi kalıplar da "hangi" sorusunun kapsamına dâhil olmaktadır. ${ }^{33}$

29 Mantık ilminde tarif, had ve resim olmak üzere ikiye ayrılır. Sonra had ve resimden her biri kendi içinde tam ve nakıs olarak iki kısma bölünmektedir. "er-Resmu'n-nakıs" şeklindeki tarifin alt başlığında lafzî tarif, misal ile tarif ve taksim ile tarif bulunmaktadır. Dolayısıyla mantık ilminde yedi tür tarif şekli vardır. "Adabu'l-bahs ve'l-münazara" eserlerinde ise tarif; hakikî, ismi, lafzî ve tenbihî olmak üzere dörde ayrılmaktadır. Bu tarif türlerinin açıklaması kısaca şöyledir: 1. Hakikî tarif: İnsanın farklı şekildeki tanımlarında olduğu gibi, dış dünyada varlığı olan bir şeyi had veya resim şeklinde tanımlamak. 2. İsmî tarif: Anka kuşunu tanımlamakta olduğu gibi, dış dünyada var olduğu bilinmeyen zihnî bir varlığı tanımlamak. 3. Lafzî tarif: Gazanferi aslan olarak tanımlamakta olduğu gibi, bir kelimeyi, muhatabın daha iyi bildiği eş anlamlısıyla tanımlamak. 4. Tenbihî tarif: Aslında muhatabın bildiği fakat o esnada unuttuğu bir şeyin anlamını ona hatırlatmak. Ayrıntılı bilgi için bkz. Abdurrahman el-Meydanî, (Davabitu'l-marife, Dımaşk: Darü'l-Kalem, 2011), 384-385.

30 Fahreddin er-Razî, el-Kaşif, 67-69.

31 Ebu Muhammed İbn Hazm, et-Takrib li haddi'l-manttk ve'l-medhalu ileyhi bi' 'l-elfazi 'l-ammiyeti ve 'l-emsileti'lfikhiyye, thk. Abdülhak b. Molla et-Türkmani, (Beyrut: Daru İbn Hazm, 2007/1428), 581-584.

32 Ebu Hamied el-Gazalî, Miyaru'l-ilim, trc. Ali Durusoy, Hasan Hacak, (İstanbul: TYEKB, 2013), 361-362; Her ne kadar burada İbn Hazm ve Gazalî’nin mantık eserlerinden alıntı yapılmışsa da bu çalışma ilgili konunun mantık eserlerinden ortaya konulması amacına sahip olmadığı için mantık eserlerinden bu konunun nasıl ele alındığının izi bu çalışmada sürülmemiştir.

33 Gazalî, Miyaru'l-ilim, 362; Razî, el-Kaşif, 68-69. 


\section{Sorunun kisımları:}

Fukaha tarafından kaleme alınan ve fikhî meseleler üzerinde cereyan eden bir münazaranın nasıl gerçekleşmesi gerektiğini ortaya koyan cedel eserlerinde sorular farklı şekillerde taksim edilmiştir. Gazalî’nin belirttiğine göre bazı cedel müellifleri sorunun iki kısma ayrıldığını ifade etmişlerdir. Bunlardan biri olan Ebu İshak el-İsferayinî’ye (ö. 418/1027) göre soru, iki kısma şöyle ayrılmaktadır:

1. Hükmü sormak: mesela "bu meseledeki hüküm nedir?" gibi,

2. Delili sormak: Mesela "Delilin nedir?" gibi. ${ }^{34}$

Bazı cedel müellifleri ise soruyu beş kısma ayırarak ele almış ve bu beş sorunun belirli bir sıralama dâhilinde sorulması gerektiğini belirtmişlerdir. Cedel müellifleri arasında özellikle Ebu'l-Velid el-Bacî’nin (ö. 474/1081) bu taksimi ve sıralamayı ayrıntılı biçimde ortaya koyduğu görülmektedir. Bundan hareketle bu çalışmada münazarada sorulması gereken sorular ve sıralama konusu, Bacî'nin açıklamaları esas alınarak ortaya konulacaktır. Burada hemen belirtmek gerekir ki Bacî’nin eseri, çok büyük oranda hocas $1^{35}$ Ebu İshak eş-Şirazî’nin (ö. 476/1083) el-Mülahhas isimli eseri ile benzeşmektedir. ${ }^{36}$

Bacî, soru sormak ve cevap vermenin beş kısımdan oluştuğunu belirtmektedir:

1. Soru sorulan kişinin ilgili meselede fikhî bir görüşünün (mezheb) olup olmadığını sormak

2. Soru sorulan kişinin görüşünün mahiyetini sorumak

3. Bu görüşün delilini sormak

4. Bu delilin soruyu nasıl açıkladığını (vech) sormak.

5. Delilde muhtemel eleştirilebilecek hususları sormak

Taklidi kabul edenler, bu sıralamada üçüncü soru olarak "soru sorulan kişinin sorulan meselede bir delili mi olduğu yoksa o meselede sadece mezhebini mi taklit ettiği” sorusunu da eklerler ve böylelikle soru ve cevap kısımlarını altıya çıkarmış olurlar. ${ }^{37}$

Şirazî, 1. Görüşü sormak, 2. Delili sormak, 3. Delilin veçhini sormak, 4. Delilde muhtemel eleştirilebilecek hususları sormak şeklinde cedelde sorunun dört kısımdan oluştuğunu ve her kısmın karşısında bir de cevap kısmı olduğunu belirtmektedir. ${ }^{38}$ Gazalî, Kadı Abdulcebbar'a (ö. 415/1025) atfederek benzer bir sıralama sunmuşs ${ }^{39}$, Razî de ayrıntılarına değinmeden benzer bir sıralamaya işaret etmiştir. ${ }^{40}$ Keza İbn Akil de "mezhebi sormak, delili sormak, delilin veçhini sormak, delildeki iddianın tashihini sormak ve ilzam sorusu" şeklindeki benzer bir sıralamayı

34 Ebu Hamid el-Gazalî, el-Müntehal fi'l-cedel, thk. Ali b. Abdülazîz b. Ali Umeyrini, (Beyrut: Darü'l-Verrak, 2004/1424), 351.

35 Şirazî’nin Bacî'nin hocası olduğu hakkında bkz. Ahmet Özel, "Bacî”, Türkiye Diyanet Vakfi İslâm Ansiklopedisi (İstanbul: TDV Yayınları, 1991), IV/414-415.

36 Bacî, büyük oranda hocasının ilgili eserini birebir aktarmıştır. Bununla birlikte bazı fıkhî mesele örneklerinde Şafîi ve Malikî mezheplerinin görüşleri aynı ise Şafîi mezhebi yerine Malikî mezhebi ismini kullanmış bazı fikhî meselelerde de Şirazî'den farklı örnekleri kendi mezhebinden sunmuştur.

37 Bacî, el-Minhac fi tertibi'l-hicac, thk. Abdülmecid Türki, (Beyrut: Dârü'l-Garbi'l-İslâmî, 1987), 34.

38 Şirazî, el-Mülahhas, 119.

39 Gazalî, el-Müntehal fi'l-cedel, 351.

40 Fahreddin er-Razî, el-Kaşif, 68. 
kelam ve fikıh alanından örnekler vererek geniş biçimde ortaya koymuştur. ${ }^{41}$ Aşağıda bu soru kısımlarından her biri ve bu sorulara verilmesi gereken cevaplar müstakil olarak ele alınacaktır.

\section{Soru sorulan kişinin bir görüşünün olup olmadığını sormak ve bu soruya cevap vermek:}

Ele alınan meseleyi karşılıklı olarak tahlil edebilmek ve böylelikle hakikati ortaya çıkarabilmek için karşılıklı düşünen ve konuşan iki kişinin belirli sorumlulukları vardır. Bu sorumluluklar, cedel eserlerinde ayrıntılı biçimde ortaya konulmuş, bu şekilde bir tahlilin neticeye ulaşabilmesi için atılması gereken adımlar tek tek sıralanarak açıklanmıştır.

Karşılıklı konuşarak bir meseleyi ele alan ve böylelikle hakikati ortaya çıkarmak isteyen kişiler, bu amaçlarına ulaşabilmek adına bilimsel/ilmî konuşmalarını/münazaralarını, kuralları belirlenmiş belirli bir sistem dâhilinde sürdürmelidirler. Taraflardan ele alınan meselede karşı tarafın görüşlerini öğrenmek isteyen kişi (sail) soru sormalı, o konuda iddiası olan diğer taraf ise (mesul) cevaplar vermelidir. Böyle bir karşılıklı ilmî konuşmada sorulması gereken ilk soru, ele alınan meselede soru sorulan kişinin ilgili meselede belirli bir görüşünün olup olmadığ 1 sorusudur. Bu soru da iki kısma ayrılmaktadır: 1. Soru sorulan kişinin ele alınan meselede doğru olduğunu düşündüğü bir görüşü olup olmadığını sormak. 2. Kendisine soru sorulan kişinin görüşünü benimseyip takip ettiği kişiden ele alınan meselede iki yaklaşım (kavl) aktarılmışsa: sorulan kişinin bu kavillerden birini tercih edip etmediğini sormak. ${ }^{42}$

Gazalî, ilk olarak sorulması gereken soru hakkında Kadı Abdulcebbar'dan alıntılayarak özetle şöyle demektedir:

Öncelikle ilgili meselede kişinin görüşü (inandığı veya mezhebi) olup olmadığı sorulmalıdır. Çünkü kişi, o meselede herhangi bir görüşün (mezhebin) doğru olduğuna inanmıyor olabilir. Bu noktada "senin görüşün/mezhebin nedir?" sorusu güzel değildir. ${ }^{43}$

İbn Akil, görüşün mahiyetinden önce kişiye ilgili meselede bir görüşü olup olmadığının sorulması gerekliliğini, 'varlık mahiyetten önce gelir' anlamındaki “el--nniyye kable'l-mahiyye (الانية قبل الماهية)" deyişiyle vurgulamaktadır. ${ }^{44}$ Şayet taraflar birbirlerinin görüşlerini biliyorsa bu sorunun düşeceği söylenmişse de, tarafların görüşlerini değiştirmiş olma ihtimali bulunduğundan yine de bu sorunun atlanmaması gerektiği de belirtilmiştir. ${ }^{45}$

Soran kişinin, ne kast ettiğinin anlaşılabilmesi ve böylelikle cevap verilebilmesi için sorusunu

41 İbn Akil, el-Vazıh fi usuli'l-fikh, I, 302-306; Bununla birlikte ortaya konulan delilden hareketle -genellikle kıyas delili üzerinden- soruların sıralamasını farklı şekillerde açıklayan cedel müellifleri de olmuştur. Mesela Gazalî, ilk sorunun men' son sorunun da muaraza olması gerektiğini ve bu ikisi arasında üç soru olduğunu ifade etmektedir. Bunlar sırasıyla ta'lilin aslının iptaline yönelik soru, illetin metnine yönelik itiraz sorusu ve nakz ile birlikte el-kavlu bi'l-mucib sorusu. Gazalî, el-Müntehal fi'l-cedel, 519-523; Razî ise soru sıralamasını şöyle vermektedir: istifsar, fesadu'l-itibar, fesadu'l-vad', ademu't-tesir, tard, men', mutalebe, fark, nakz, kesr, kalb, muaraza, el-kavlu bi'l-mucib. Razî, el-Cedel, 150.

42 Bacî, el-Minhac fi tertibi'l-hicac, 34-35.

43 Gazalî, el-Müntehal fi'l-cedel, 351.

44 İbn Akil, el-Vazıh fi usuli'l-fikh, I, 306-307.

45 İbn Akil, el-Vazıh fi usuli'l-fikh, I, 313. 
açıklaması gerekmektedir. Soru açıklandıktan sonra sorulan kişi, soruya cevap vermelidir. Yukarıda belirtilen soru çeşitlerine göre soru sorulan kişinin, ilgili meselede bir görüşünün olup olmamasından ve şayet birinin görüşünü benimsemişse o kişiden söz konusu meselede birden fazla yaklaşım rivayet edilip edilmemesinden hareketle kişinin doğru olduğunu düşündüğü görüşü ve tercih ettiği yaklaşımı açık bir biçimde ifade ederek cevap vermesi gerekmektedir. ${ }^{46}$

\section{Soru sorulan kişinin görüşünün mahiyetini sormak ve bu soruya cevap vermek}

Ele alınan meselede, kişi kendi görüşünün ne olduğunu belirttikten sonra Bacî’ye göre ona görüşünün mahiyeti sorulur. Fakat Gazalî’nin aktardığına göre Kadı Abdulcebbar, bu aşamada sorulması gereken farklı sorular olduğu görüşündedir. Ona göre bu aşamada sorulması gereken sorular şöyledir:

Kişiye ele alınan meselede belirli bir görüşü olup olmadığ 1 sorulduktan sonra ona "Senin bu görüşün delillendirilebilir midir, yoksa delille açıklanamayanlardan mıdır?" diye sorulması gerekir. Zira kişi ilgili meselede bir görüşün doğru olduğuna inanıyor fakat bu görüşün delillendirilemez olduğuna inanıyor olabilir. Bu sebepten ötürü bu noktada bu sorudan önce delili sormak uygun değildir. Şayet kişi görüşünün delillendirilebilir olduğuna inanıyorsa üçüncü olarak şu soru sorulur:

“Sen delili biliyor musun?” Çünkü kişi delili bilmeden taklidî olarak inanıyor olabilir. Şayet kişi delili bildiğini söylerse şu soru sorulur:

"Sen delilini güzel biçimde ortaya koyabilir misin? Çünkü kişi ilgili meseledeki delili güzel biçimde açıklamaktan aciz olabilir. ${ }^{47}$

Görüldüğü üzere Gazalî, ele alınan konuda kişinin görüş açıklayabilmesi için kişinin 1. O görüşün delillendirilebilir olduğunu inanmasını, 2. Görüşünün delilinin bilmesini ve 3. O delili güzel biçimde açıklayabilmesini gerekli görmüştür. Bu açıklamalardan hareketle kişinin bu vasıflara sahip olmadan da bir mezhebe/görüşe mensup olmasının mümkün olduğu fakat bu vasıflara sahip olmadan görüşünü açıklamaya kalkışmasının hoş karşılanmadığı anlaşılmaktadır.

Yukarıda da belirtildiği üzere Bacî’ye göre bu aşamada kişinin görüşünün mahiyeti sorulmalıdır. Soru sorulan kişinin görüşünün mahiyetini sormanın iki şekilde olabileceği ifade edilmektedir. Buna göre ele alınmak istenilen meselenin hükmü ya doğrudan ya da cevabı hükmü açıklayacak şekilde hükmün ortaya konulma yöntemi (tarik) sorulabilir. Bu tarik; isim, sıfat, illet veya rivayet/haber olabilir. Bunlara verilecek cevabın aynı zamanda hükmün ne olduğunu da açıklayacağını ve bu sebeple bu soruların hükmü sormak gibi kabul edildiğini ifade eden Şirazî ve Bacî, konuyu şöyle açıklamaktadırlar:

A. Kullanılan ismin ne anlama geldiği sorulabilir. Örnek olarak nebizin hamr olarak isimlendirip isimlendirilmediği veya madenin rikaz olarak isimlendirilip isimlendirilmediği sorulabilir.

B. Hükmün kendisine taalluk ettiği sıfat sorulabilir. Örnek olarak dini hükmünü belirleyebilmek

46 Bacî, el-Minhac fi tertibi'l-hicac, 35.

47 Gazalî, el-Müntehal fi'l-cedel, 352. 
için kıl ve kemikte ruh olup olmadığ 1 sorulabilir.

C. Hükmün illeti sorulabilir. Örnek olarak hamrın haram kılınma illetinin ne olduğu sorulabilir.

D. Hükmün tariki (ortaya konulma yöntemi) haber ise hükmü belirleyebilmek adına o haber hakkında soru sorulabilir. Örnek olarak Peygamber Efendimizin (sav) ifrad hacc1 m1 yoksa kıran haccı mı yaptığı veya Mekke fethinin savaş yolu ile mi yoksa sulh yolu ile mi gerçekleştiği sorulabilir. ${ }^{48}$

$\mathrm{Bu}$ açıklamalardan hareketle şunları söylemek mümkündür: İlmi araştırmalarda cevabı istenilen soru doğrudan sorulmalıdır. Herhangi bir sebepten ötürü bu soru doğrudan ortaya konulamıyorsa, ilgili sorunun cevabını farklı şekillerde açığa çıkaracak başka soruların neler olduğu araştırılmalı ve onlar üzerinden cevap açığa çıkarılmaya çalışılmalıdır.

Şirazî ve Bacî, bu aşamada soru soran kişinin soru sorarken sorusunu içerisinde birçok farklı meseleyi barındıracak şekilde mücmel ve mübhem biçimde sormamaya ve soru esnasında kendisini ilzam edecek ifadelerden sakınmaya dikkat etmesi gerektiğini belirtmektedir. ${ }^{49}$ Görüldüğü üzere bu aşamada sailin, cevabını öğrenmek istediği meselede ya hükmü doğrudan sorması ya da hükmü dolaylı olarak ortaya koyacak bir soru sorması beklenmektedir. Sailin bu esnada cevabını istediği meselenin ne olduğunu hem açık hem de farklı ihtimallerden arındırılmış bir şekilde sorması istenilmektedir. Bu tutumun, cedelde olduğu kadar araştırmalarda (bahs) da gösterilmesi gerektiğini söylemek mümkündür.

$\mathrm{Bu}$ aşamada kendisine soru sorulan kişi, soru soran kişinin kafasını karıştırmayacak ve aldığı cevabı doğrudan uygulamaya yansıtabilmesini sağlayacak açıklıkta cevap vermelidir. Fakat soru soran kişiye, hükmün ortaya konulma yöntemleri de öğretilmek isteniyorsa o halde diğer görüşleri ve onların neden yanlış olduğunu da cevap veren kişi açıklayabilir. ${ }^{50}$

$\mathrm{Bu}$ aşamada sorulan sorunun birden fazla meseleyi kapsamayacak şekilde açık olması gerektiği yukarıda ifade edilmişti. Fakat buna rağmen sorulan meselede farklı durumlara göre tafsilatlar ve farklı yaklaşımlar varsa, yukarıdaki ifadelerden de anlaşıldığı üzere cevap verenin ya ayrıntıları açıklayarak cevap verebileceği ya da soru sorandan sorusunu belirginleştirmesini isteyebileceği söylenmiştir. ${ }^{51}$

Bu aşamada, tıpkı soru soran kişi gibi, cevap veren kişi de cevap verirken kendisini ilzam edecek genel sözler söylemekten sakınmalıdır. Zira bazen cevap veren kişi, verdiği genel cevap ile kendisini ilzam eder ve sonrasında sözünden dönmesi mümkün olmaz. ${ }^{52}$

İbn Akil, kişinin görüşünü ve delilini sormaktan ibaret olarak gördüğü bu ilk iki soruda karşı tarafın her hangi bir eleştiride bulunamayacağını belirtmektedir. ${ }^{53}$

48 Şirazî, el-Mülahhas, 120-121; Bacî, el-Minhac fi tertibi'l-hicac, 35.

49 İlgili eserlerde sorunun mücmel ve mübhem sorulması hakkında şöyle denilmektedir: “Çünkü riba konusunun içerisinde birçok başlık ve mesele vardır ve böyle bir soru karşısında kendisine soru sorulan kişi soran kişinin ribanın hangi başlığını, hangi meselesini sorduğunu anlayamaz.” Şirazî, el-Mülahhas, 121; Bacî, el-Minhac fi tertibi'l-hicac, 35-36.

50 Bacî, el-Minhac fi tertibi'l-hicac, 36; Şirazî, el-Mülahhas, 121-123.

51 Bacî, el-Minhac fi tertibi'l-hicac, 36; Şirazî, el-Mülahhas, 121-123.

52 Bacî, el-Minhac fi tertibi'l-hicac, 36; Şirazî, el-Mülahhas, 121-123.

53 İbn Akil, el-Vazıh fi usuli'l-fikh, I, 303. 


\section{Delilini sormak ve bu soruya cevap vermek}

Soru sorulan kişi, ele alınan meselede görüşünü açıkladıktan sonra soran kişi, "bunun delili nedir? diye sorarak soru sorulan kişiden delilini açıklamasını ister. Kadı Abdulcebbar da "sen delilini güzel biçimde ortaya koyabilir misin?” sorusundan sonra beşinci olarak kişiye delilinin ne olduğunun sorulacağını ifade etmektedir. ${ }^{54}$

İlgili cedel eserlerinde bu kısmın iki farklı aşamada ele alındığg görülmektedir. İlk aşamada, cevap veren kişinin sunacağı delil ve açıklamaların yöntemini belirleyebilmek adına soru soran kişinin belirli bir görüşü olup olmadığını öğrenebileceği söylenmektedir. İkinci aşamada ise meseleyi nasıl delillendirebileceği açıklanmaktadır. İlk aşamada cevap verecek olan kişi, soru soran kişinin görüşünü biliyorsa kendi görüşünün doğruluğunu veya soru soran kişinin görüşünün yanlışlığını deliller ile açıklayabilir. Cevap verecek olan kişi soru soranın görüşünü bilmiyor ve farklı görüşlerden hareketle deliller farklılık arz ediyorsa cevap verecek olan kişi öncelikle soru soranın görüşünü sorar. ${ }^{55}$

Bu kısımda yer alan ikinci aşamada yani meselenin nasıl delillendirilebileceği aşamasında, kendisine soru sorulan kişinin görüşünü açıklarken üç farklı yol (tarik) kullanabileceği söylenmektedir:

1. Sorulan meselenin kendisine dair delil zikretmek: Soru sorulan kişinin bu yöntem ile cevap vermesi kesin olarak caiz görülmüştür. Cevap verirken bu yöntemi kullanmak isteyen kişinin önüne, cevabın has veya âm olmasından hareketle iki seçenek konulmuştur:

A. Sorulan meseleye özel/has bir delil zikretmek: Mesela bir temizlenme türü olan abdestte niyetin farz olduğu görüşünü delillendirmek isteyen kişinin abdestin de tıpkı teyemmüm gibi belirli azalara sirayet eden bir taharet olduğunu ve teyemmümde niyetin farz olması gibi abdestte de farz olması gerektiğini söylemesi buna örnektir. ${ }^{56}$ Bu cevap yönteminde, bir temizlenme türü olan abdestte niyetin farz olduğunu delillendirmek isteyen kişi, bunu yine bir temizlenme türü olan teyemmümde niyetin farz olduğunu göstererek gerçekleştirmeye çalışmıştır.

B. Sorulan meseleyi de kapsayan umumi bir delil zikretmek: Abdestte niyetin farz olduğu görüşünü dellilendirmek isteyen kişinin abdestin de tıpkı namaz gibi bir ibadet olduğu ve ibadetlerde niyetin farz olduğunu söylemesi buna örnektir. ${ }^{57} \mathrm{Bu}$ cevap yönteminde, abdestte niyetin farz olduğunu delillendirmek isteyen kişi, abdesti bir ibadet olarak kabul ettikten sonra abdesti de kapsayacak şekilde umumi bir delil üzerinden ibadetlerde niyetin farz olduğunu belirterek gerçekleştirmeye çalışmıştır.

2. Sorulan meselenin bazı fasıl ve alt başlıklarına/şubelerine dair delil zikretmek: Bacî ve Şirazî, burada farz konusunu ele almıştır. Farz konusu, bu çalışmada müstakil bir başlık altında ele alınacağından ilgili açıklamalar ortaya bırakılmıştır.

3. Sorulan meseleyi başka bir mesele üzerine bina etmek: Cedel eserlerinde cevap verirken

54 Gazalî, el-Müntehal fi'l-cedel, 352.

55 Bacî, el-Minhac fi tertibi'l-hicac, 26-27; Şirazî, el-Mülahhas, 123.

56 Bacî, el-Minhac fi tertibi'l-hicac, 37; Şirazî, el-Mülahhas, 124.

57 Bacî, el-Minhac fi tertibi'l-hicac, 37; Şirazî, el-Mülahhas, 124. 
farz yapmanın caiz olup olmaması ile birlikte ele alınan bina konusu da müstakil olarak ele alınacaktır.

\section{Delilin soruyu nasıl açıkladığını (vech) sormak ve bu soruya cevap vermek}

Görüşünü belirten kişiye delili sorulduktan ve kişi delilini açıkladıktan sonra, delilin medlule ne açıdan delalet ettiği yani ele alınan meseleyi nasıl açıkladığı sorulur. Cevap veren kişi sorulan soruya cevap olarak ayet veya hadis (haber) zikretmiş de soran kişi zikredilen ayet veya hadisin meseleyi açıklayan yönünü anlamamışsa, delilin meseleyi nasıl açıkladığının/ medlule nasıl delalet ettiğinin belirtilmesini isteyebilir. Zira ortaya konulan delil ya açıktır (vazıh) ya da kapalıdır (ğamid).

Ortaya konulan delil şayet açık ise bu delilin meseleyi nasıl açıklandığının sorulması hoş karşılanmaz. Bu yönüyle delilin açık olmasının üç şekli olabilir: nas, zahir ve umum ${ }^{58}$ ki delil böyle açık olduğunda delilin meseleyi nasıl açıkladığının sorulması hoş karşılanmaz. Fakat ortaya konulan ayet veya haberin delil olma bakımında iki vechi söz konusu ise bu durumda soru soran kişi, cevap olarak bu ayet veya hadisi zikreden kişinin delilin hangi veçhini kast ettiğini (itimad) sorabilir. Mesela abdestte niyetin farz olduğu görüşünde olan biri, delil olarak "Ameller niyetlere göredir ve herkese niyet ettiği vardır" $" 59$ hadisini zikretmiş olsun. Bu hadiste "ameller niyetlere göredir" ve "herkese niyet ettiği vardır” şeklinde iki delil vardır. Bu durumda soru soran kişi cevap verenin hangi delile dayandığını sorabilir ve böylelikle konuşmanın belirtilen kısım üzerinden devam etmesi sağlanmış olur.

Ortaya konulan delilin hükme delaleti şayet kapalı ise, soru soran kişinin açıklama istemesi (mutalebe) güzel bir davranıştır. Örneğin Malikîler alacağı havale edilen kişinin (muhal), ödemesi için kendisine havale edilen kişinin (muhal aleyh) iflas etmiş biçimde ölmesiyle tekrar borcu havale eden asıl borçluya (muhil) rücu’ edemeyeceği görüşündedirler. Bu görüşlerine şu hadis ile istidlal etmişlerdir: "Zengin olan kişinin borcunu ödemeyi ertelemesi zulümdür. Sizden biri, hali vakti yerinde olan birine havale edildiğinde, bu havaleyi kabullenip o kişiye müracaat etsin." ${ }^{90}$ Bu hadisin ele alınan meseleye nasıl delalet ettiği açık olmadığg için bu hadisin meselede delil olarak nasıl kullanıldı̆̆ının açıklanmasının istenilmesi uygun olur. Bu durumda cevap veren kişi zikrettiği hadisin ele alınan meselede delil olma yönünü açıklamalıdır. Şöyle

58 Nas: Bacî, nasın örneği olarak Peygamber Efendimizin "cinsel ilişki olduğunda meni gelse de gelmese de gusül gerekir" ifadesinden ötürü Malikîlerin cinsel ilişkinin guslü gerektirdiğine dair istidlallerini örnek verir. Şirazî ise nas örneği olarak Peygamber Efendimizin "boşama erkekler, iddet ise kadınlar içindir" ifadesinden ötürü Şafîilerin boşama yetkisinin erkeklerde olduğuna dair istidlallerini örnek verir. Zahir: Bacî, zahir örneği olarak Peygamber Efendimizin hayızlı veya cünüp olan kişinin Kuran-1 Kerim okuyamayacağını belirttiği ifadelerden hareketle Malikîlerin cünüp veya hayızlı kişinin Kuran okuyamayacağına dair istidlallerini örnek verir. Şirazî, Peygamber Efendimizin hayız kanının yıkanmasına yönelik ifadesinden ötürü Şafiîlerin necesetin ancak su ile izale edilebileceğine dair istidlallerini örnek verir. Umum: Her iki cedel müellifi de bu başlık altında Peygamber Efendimizin dinini değiştirenin öldürülmesini emreden ifadesinden ötürü mürtedin öldürülmesine dair kendi mezheplerinin istidlallerini örnek verir. Bk. Bacî, el-Minhac fi tertibi' 'l-hicac, 39; Şirazî, el-Mülahhas, 133-134.

59 İbn Mâce, "Niyet", 26, (4227).

60 İbn Mâce, "Havale", 8, (2404). 
ki, hadiste borcun havale edildiği kişinin "hali vaktinin yerinde olması" şart koşulmuştur. Bu şart, alacaklı olan kişinin hakkının/malının telef olmaması için konulmuştur. Şayet ödemesi için havale edilen kişi ödeyemediğinde alacaklının havale eden kişiye rücu' hakkı olsaydı, "hali vakti yerinde olma" şartının bir anlamı kalmamış olurdu zira (rücu' hakkının olması durumunda) ödemesi için havale edilen kişi hali vakti yerinde olsa da olmasa da her hâlükârda alacaklının hakkı telef olmamıs olurdu. ${ }^{61}$

Bacî’ye göre soruların bu sıralama ile sorulması gerekir ve soru soran kişinin henüz delili veya delilin veçhini sormadan eleştiriye başlaması caiz değildir. Bacî, bazı nazar ehlinin bunun caiz olduğunu söylediğini fakat kendisine göre bunun yanlış olduğunu söylemektedir çünkü ona göre bu durumda soru soran kişi sorulan kişi haline gelmiş olur ki böyle bir hakkı yoktur. ${ }^{62}$

Fakat Kadı Abdulcebbar, delil sorulduktan ve cevap verildikten sonra başka bir soru sorulması gerektiği görüşündedir. Ona göre sorulması gereken altıncı soru, "Bunun delil olduğuna dair delilin nedir?” sorusudur. O, neden böyle bir sorunun gerekli olduğunu şöyle açıklamaktadır:

Zira birçok kişi aslında delil olmayan şeyin delil olduğuna inanmaktadır. Mesela Ahmed b. Hanbel'in rivayet ettiğine göre biri, Kuran'ın mahluk olduğunu söyleyenin öldürüleceği yönünde fetva vermiş, Ahmed b. Hanbel bu durumu kendisine sorunca şöyle bir delil ortaya koymuş: Adamın biri rüyasında İblis’i bir beldenin kapısından dönerken görmüş ve “o beldeye girmeyecek miydin?” diye sormuş. İblis “orada Kuran'1n mahluk olduğunu söyleyen biri var, bu yüzden benim oraya girmeme ihtiyaç kalmadı" demiş ve adam uyanmış. Ahmed b. Hanbel, "Şayet sen uyanıkken İblis benim öldürülmem gerektiği şeklinde fetva verse, bu fetvaya uyar mısın?" deyince adam "hayır" demiş. Bunun üzerine Ahmed b. Hanbel "onun rüyada söylediği, uyanıkken söylediğinden daha kıymetli değildir" demiş. ${ }^{63}$

Burada ilmi bir konuyu karşılıklı ele alan kişilerin, ele aldıkları konunun delillerinin neler olduğunu ve nelerin delil olarak kabul edilmediğini bilmelerinin öneminin vurgulandığ görülmektedir. Yukarıda ifade edildiğine göre ilmî bir konu ele alınırken, aslında kabul edilmemesi gereken bir şeyi delil olarak kullanmak, tarafların sıklıkla düştükleri sakınılması gereken bir hata olagelmiştir.

\section{Delilde muhtemel eleştirilebilecek hususları sormak ve bu soruya cevap vermek}

Bu aşamada, ortaya konulan delilin tashih edilmesi veya düşürülmesi için eleştiri soruları sorulmaktadır. Bu yönüyle eleştiri amacıyla delile dair sorular sormak üç kısımdan oluşmaktadır: mutalebe, itiraz ve muaraza.

Mutalebe: Sail mutalebe ile müstedilden ortaya koyduğu delilin usul açısından gerekli şartları taşıyıp taşımadığını tashih etmesini istemektedir. Ortaya konulan delilden hareketle mutalebe örnek olarak şu şekillerde olabilir: 1. Ortaya konulan rivayetin tashih edilmesi ve

61 Bacî, el-Minhac fi tertibi'l-hicac, 39-40; Şirazî, el-Mülahhas, 132-133.

62 Bacî, el-Minhac fi tertibi'l-hicac, 40.

63 Gazalî, el-Müntehal fi'l-cedel, 351-353. 
senedinin ortaya konulmasını istemek. 2. Ortaya konulan icma' delilinin tashih edilmesi ve ispat edilmesini istemek. 3. Ortaya konulan kıyas delilinde illetin tashih edilmesini istemek. Bundan başka mutalebe şekilleri de olabilir. Bu durumda kendisine soru sorulan kişinin cedel eserlerinde açıklandığ 1 şekilde ortaya koyduğu delili tashih etmesi gerekmektedir. ${ }^{64}$ Cüveynî, delilin açıklanmasını istemek anlamına geldiğini belirttiği mutalebenin iki kısma ayrıldığını söylemektedir: 1. Ortaya konulan delilin aslının açıklanması ve ispat edilmesini istemek. 2. Delilin ilgili meseleye nasıl delalet ettiğinin açıklanmasını istemek. ${ }^{65}$ Cüveynî’nin mutalebinin ikinci kısmı olarak zikrettiği aşamayı, Şirazî ve Bacî sorunun dördüncü kısmı olarak zikretmişlerdir. Ortaya konulan delilin sıhhatinin sorgulanması anlamında mutalebe aşamasının, sorunun üçüncü kısmından sonra yer alması kanaatimizce daha uygun olurdu. Fakat mutalebenin bu başlık altında yer alması, mutalebinin delilin gerçekliğine eleştiri mahiyetinde görülmesi ile açıklanabilir.

İtiraz: $\mathrm{Bu}$, delilin bizzat kendisine o delili iptal edecek şekilde itiraz etmektir. Mesela: ravilerin zayıf olduğunu söyleyerek ortaya konulan rivayetin senedine dair eleştirilerde bulunmak. Farklı görüşü (hilaf) ortaya koyarak icma' iddiasına eleştiride bulunmak. Nakz ve kesr ile illete dair eleştirilerde bulunmak. Bundan başka itiraz şekilleri de olabilir. ${ }^{66} \mathrm{Bu}$ durumda kendisine soru sorulan kişi, bu eleştirilerin haksızlığını ortaya koymak ve delilinin kabul edilmesini sağlamak zorundadır. ${ }^{67}$

Muaraza: Soru soran kişinin ortaya konulan delilin benzeri veya daha güçlüsü ile karşılık vermesidir. Cevap veren kişinin ortaya koyduğu delile yönelik bu eleştirileri cevaplaması gerekmektedir. ${ }^{68}$

Eleştiri sorularının bu sıralama ile sorulması gerekli görülmüştür. Konuyla ilgili olarak Şirazî şöyle demektedir:

64 Bacî, el-Minhac fi tertibi'l-hicac, 40-41; Şirazî, el-Mülahhas, 137.

65 Cüveynî, el-Kafiye fi'l-cedel, 68.

66 İtiraz, çalışmanın girişinde de belirtildiği üzere cedelin temel rükünlerinden biri olarak da kabul edilmiştir. Bu yönüyle bazı cedel eserlerinde itiraz, burada yer aldığı şekliyle değil de ortaya konulan delilden hareketle mesela "kıyas deliline yöneltilebilecek itirazlar" şeklinde yer almaktadır. Bkz. İbn Akil, el-Vadıh, II, 192-299; Tufî, Alemü'l-cezel fi ilmi'l-cedel, 55-80; Mesela Cüveynî ve Gazalî itiraz başlığını daha genel bir başlık olarak ele almışlar ve itiraz başlığının altında bir çok itiraz çeşidine yer vermişlerdir. Cüveynî mutalebe, beyanu fesadi'lvaz', dava'l-iştirak, munakaza, el-kavlu bi'l-mucib, fark ve muarazanın itirazın türleri olduğunu söylemiştir. Cüveynî, el-Kafiye fi'l-cedel, 67-68; Gazalî istidlal türlerini verdikten sonra bu delillere nasıl itiraz edileceğini açıkladığı bu başlık altında mutalebe, el-kavlu bi'l-mucib, nakz ve muarazanın da yer aldığı on (10) tane aşama zikretmektedir. Gazalî, el-Müntehal fi'l-cedel, 393-495.

67 Bacî, el-Minhac fi tertibi'l-hicac, 41; Şirazî, el-Mülahhas, 137-138.

68 Bacî, el-Minhac fi tertibi'l-hicac, 41; Şirazî, el-Mülahhas, 138. Her iki müellif de delile dair bu eleştirilerin ayrıntılarını delillerin sıralanması konusunda tek tek açıklayacaklarını ve bu eleştirilere nasıl cevap verilebileceğini de o kısımda ortaya koyacaklarını ifade etmektedirler. Nitekim cedel eserlerinde deliller ve itirazlar açıklanırken, itirazlar başlığı altında ortaya konulan delilden hareketle birçok soru sorulabileceği ifade edilmiştir. Örneğin Razî, itiraz başlığı altında sırasıyla şu sorulara yer vermektedir: istifsar, fesadu'l-itibar, fesadu'l-vaz', ademü't-tesir, tard, men', mutalebe, fark, nakz, kesr, kalb, muaraza, el-kavlu bi'l-muceb. Bk. Razî, el-Cedel, "Fahreddin erRazî’nin el-Cedel Adlı Eserinin Tahkikli Neşri”, nşr./thk. Ahmet Numan Ünver, (Tahkik İslami İlimler Araştırma ve Neşir Dergisi 3/2, Aralık/December 2020), 111-159. 
Önce itiraz sonra mutalebe soruları caiz değildir. Çünkü itiraz, ancak o delil sabit olduktan sonra yapılabilir. Önce itiraz sonra mutalebe halinde ise kişi önce kabul ettiğinden sonra dönmüş olur ki bu caiz değildir. Aynı şekilde önce muaraza sonra itiraz eleştirilerini yapması da caiz değildir. Çünkü muaraza, karşı tarafın ortaya koyduğu delilin selametini kabul etmek anlamına gelmektedir. Önce muaraza sonra itiraz eleştirisinde bulunmak ise kişinin kabul ettiğinden dönmesi anlamına gelir ki bu caiz değildir. ${ }^{69}$

Cedel esnasında soruların genel olarak önce anlama, sonra delilin gerçekliğini ve ele alınan meseleye uygunluğunu soruşturma ve son olarak da tutarlığının ve ilgili diğer deliller karşısında neden tercih edilmesi gerektiğinin öğrenilmesi amacıyla sıralandığını söylemek mümkündür. Nitekim Gazalî, İbn Akil ve Razî de benzer gerekçelerle soruların belirledikleri sıralama ile sorulması gerektiğini ifade etmektedirler. ${ }^{70}$ Cedel eserlerinde genel tutum bu olmakla beraber Tufî, ihtilaflı olduğunu belirttiği bu konuda soruların belirli bir sıralama ile sorulmasının daha güzel ve anlaşılır olduğunu fakat düzensiz olarak sorulmasının ise hem daha kolay olduğunu hem de yine amaca eriştirdiğini belirtmektedir. Aynı şekilde cevapların belirli bir sıralama ile ortaya konulmasının da zarurî değil tahsinî ve tekmilî olduğunu ifade etmektedir. ${ }^{71}$

Fukaha tarafından telif edilen cedel eserlerinde soru sormanın kısımları ve aşamaları genel olarak bu şekilde ortaya konulmuştur. Bunlar dışında soru sormak ile ilgili olarak ele alınan bir başka mesele de, soru soran kişinin bir delil hakkında birden fazla soru sormasının uygun olup olmadığıdır. Soru soran kişinin bir delil hakkında birden fazla soru sorma hakkının olup olmadığı konusunda ihtilaf edildiği söylenmektedir. "Soru soranın delil hakkında birden fazla soru sorma hakkı yoktur, aynı şekilde delillendirmede bulunanın da birden fazla delil ortaya koyma hakk1 yoktur” görüşünü ortaya atanlar olmuştur. Bacî bu görüşe katılmadığını belirterek şunları söylemektedir:

Zira soru soranın amacı öğrenmektir (müsterşid) ve dolayısıyla ortaya konulan delile tam olarak güvenebilmesi için aklındaki tüm şüpheleri ortaya koyup izale etmesi gerekmektedir. Delil ortaya koyan kişi delilinin bir yönü ile sağlam olduğunu ortaya koyup diğer eleştiri yönlerinden sağlam olduğunu ortaya koymaz ise soru soranı irşad etmiş olmaz. ${ }^{72}$

Şirazî de her aşamada soru soranın bir veya ikiden fazla soru sormasının konuşmanın karıştırılmasına sebep olabileceğini fakat bunun caiz olduğunu, bir veya ikiden fazla soru sormamanın ise bu sebepten ötürü sadece evla olduğunu belirtmektedir. Aynı şekilde O, cevap verenin de her aşamada bir veya iki cevap vermesinin evla olduğunu, zira fazla cevap verilmesi halinde doğrunun gizli kalabileceğini ifade etmekte fakat daha fazla cevap vermenin de caiz olduğunu söylemektedir. ${ }^{73}$ Tufî, cedelde soruların nasıl sorulması gerektiği hakkında ihtilaf edildiğini belirtmektedir. Ona göre aralarında Ebu Ya’la (ö. 458/1066) ve İbn Akil

69 Şirazî, el-Mülahhas, 138-139.

70 Gazalî, el-Müntehal fi'l-cedel, 519-523; İbn Akil, el-Vazıh, I, 303-306; Razî, el-Cedel, 149-150.

71 Tufî, Alemü'l-cezel fi ilmi'l-cedel, 81 .

72 Bacî, el-Minhac fi tertibi'l-hicac, 41.

73 Şirazî, el-Mülahhas, 138. 
gibi kişilerin de yer aldığı mütekaddimin, soru soran kişinin sorularını sırayla sorması, ancak cevabını aldıktan sonra diğer soruya geçmesi, sorularının tümünü birden sormaması gerektiği görüşündedirler. Buna karşın Razî ve takipçilerinin de yer aldığı müteahhirin soru soran kişinin sorularını henüz cevap almadan peş peşe sorabileceği görüşündedir. Tufî’ye göre ilk tutum, soru ve cevabın anlaşılması açısından daha faydalıyken ikinci tutum ise delillerin birbiri ile ilişkisi de ortaya konularak arka arkaya açıklanabilmesi açısından hakikatin ortaya çıkarılması açısından daha faydalıdır. ${ }^{74}$

\section{Doğru soruyu yanlışından ayırmak}

Soru kelimesinin anlamı, soru edatları ve kısımları açıklandıktan sonra şimdi de soru ve cevap diyaloğunda ortaya çıkması muhtemel hatalardan hareketle doğru soru ve cevabı yanlışlarından ayırmak için cedel müelliflerinin ortaya koyduğu ilkelere geçilecektir. Görebildiğimiz kadarıyla cedel eserlerinde dağınık şekilde yer alan bu konuyu en sistemli şekilde ele alan isim Gazalî’ dir. Bu sebeple aşağıda Gazalî’nin ortaya koyduğu sistem üzerinden bu başlık ele alınacaktır.

Soru soran kişi, kendisine gizli olan konuyu öğrenmek maksadıyla sorular sormalıdır. Bundan hareketle Kadı Abdulcebbar, kendisi için belirsizlik olan konularda kişinin soru sorması doğrudur demiştir. Sorunun dört rüknü vardır: 1. Soru soran, 2. Sorulan konu, 3. Kendisine soru sorulan, 4. Anlaşılmak istenilen konu. Bir soru, bu rükünlerden herhangi birinde ortaya çıkan hatadan ötürü fasid olabilir.

\section{Soru soran kişiden kaynaklı hatalar:}

Gece ve gündüzün varlığı (sebebi değil) gibi herkes tarafından bilinen ve çok açık olan (bedihî ve zarurî $\hat{n}^{75}$ ) konularda soru sormak, öğrenmek kasıtlı değil alay ve inat etmek amaciyla sorulan sorular olarak kabul edildiğinden batıl olarak değerlendirilmiştir.

Bundan hareketle şu mesele ortaya çıkmaktadır: Sofistlerin safsataya bağlı soruları dikkate alınmalı mıdır yoksa batıl olduğuna mı hükmedilir? Bu konuda iki farklı yaklaşım ortaya konulmuştur. Bu soruların dikkate alınması gerektiğini belirten Kadı Abdulcebbar (ö. 415/1025) şöyle demiştir:

Her ne kadar içinde zarurî olarak inkârı barındırsa da bu sorular inanç ve mezheb ile alakalı sorulardır. Mesela Kâbî’nin (ö. 319/931), tevatür bilgisinin zarurî bilgiyi ortaya çıkarıp çıkarmadığına dair sorusu buna örnektir. Onun bu sorusu her ne kadar kabul ettiği inanç ve mezhep olan zarurî bilginin zannî olanla ilgisine dayanıyor olsa da dikkate alınır. ${ }^{76}$

Bu tür soruların dikkate alınmaması gerektiği görüşünde olan İmam Cüveynî ise bu görüşünü şöyle açıklamıştır:

74 Tufî, Alemü'l-cezel fi ilmi'l-cedel, 80-81.

75 Bedîhiyyât: aklın hiçbir delile ihtiyaç duymaksızın apaçık ve kesin olarak kabul ettiği önermeler. Zarûriyyât: zihnin zorunlu olarak kabul ettiği, kesin bilgi içeren önermeler. Ayrıntılı bilgi için bkz. Mustafa Çağrıcı, "Zarûriyyât", Türkiye Diyanet Vakfi Íslâm Ansiklopedisi (İstanbul: TDV Yayınları, 2013), XXXXIV/146-148. 


\begin{abstract}
Zarurî olarak bilinenler konusunda soranlar, engellenemez bir inat ve önlenemez bir cehalet içerisindedirler. Zira soruya deliller ile cevap veren kişinin amacı, delilini herhangi bir düzeydeki zarurî bilgiye dayandırmak veya bağlamaktır. Soru soran zarurî bilginin kendisini inkâr ettiğinde onunla konuşmak mümkün olmaz. O, gece gündüzü soran ve hiçbir mezheple alakalı olmayan konuları soran kişi gibidir. Kâbî'nin sorusu ise sahihtir, çünkü o, tevatür haberlerle bilginin oluşacağını inkâr etmemektedir. $\mathrm{O}$, bu bilginin hangi cihetten oluşacağını teyit etmektedir. Bu ise, “el-Menhul min ta'liki'l-usul”da açıkladığımız üzere kapalılığın olduğu bir konudur. ${ }^{77}$
\end{abstract}

$\mathrm{Bu}$ farklı yaklaşımlardan anlaşıldığına göre şayet soru soran kişi samimi olarak hakikat arayışında ise bu kişinin apaçık konulardaki şüpheleri ve soruları da dikkate alınarak cevap verilir. Buna karşın soru soran kişi sadece inadından veya herhangi bir temel bilgi düzeyini dahi anlayamamasından ve inkar etmesinden kaynaklı sorular soruyorsa bu kişinin soruları dikkate alınmaz. Söz konusu ayırımdan hareketle bilimsel istişare ve tartışmaların inat ve inkar eden kişilerle değil, samimi olarak hakikat arayışında olan kişilerle yapılması gerektiğini söylemek mümkündür.

\title{
2. Sorudan kaynaklı hatalar:
}

İlmî bir tartışmanın/araştırmanın sahih biçimde ilerleyebilmesi için ele alınan konunun ne olduğunun anlaşılması ve bunun için de açık bir şekilde ortaya konulması gerekmektedir. Bundan hareketle ilmî olarak ele alınması ve araştırılması/tartışılması istenilen mesele şayet kapalı ve farklı meselelerden ayrıştırılmamış biçimde sorulur/ortaya konulursa bu durumda kendisine soru sorulanın isterse cevap vermeyebileceği isterse de sorudaki hatayı karşısındakine bildirebileceği ifade edilmiştir.

Sorunun yukarıda anlatıldığı şekilde açık biçimde ortaya konulması "hasir has", kapalı ve farklı meselelerden ayrıştırılmamış biçimde ortaya konulması ise "mürsel mücmel” olarak isimlendirilmiştir. Çoğunluk, umum ifade eden soruların batıl olduğu görüşündedir. Örnek olarak "hurma nebizi hakkında görüşün nedir?" sorusunun "mübhem mürsel” bir soru olduğu kabul edilmiştir. Zira hurma nebizi hakkında fikıhta farklı başlıklar altında meseleler vardır fakat burada hurma nebizinin necis olduğu mu, içilmesinin helal olup olmadığı mı, helak edilmesi halinde tazmin edilmesinin gerekli olup olmadığı mı veya onunla abdest alınıp alınamayacağının mı sorulduğu belirli değildir. Bu sorunun "hasir has" olabilmesi için sorunun mesela "Sefer halinde su yokken hurma nebizi ile abdest almak caiz midir?" şeklinde açık biçimde ortaya konulması gerektiği ifade edilmiştir.

Bununla beraber, şayet soru umumi olarak sorulmuş olsa bile sorulan konunun içeriğinin ne olduğu hakkında o çevrelerde yaygın bir örf varsa bu soruların mübhem olmadığı da söylenmiştir. Mesela İmam Cüveynî, hurma nebizi hakkında yaygın örf olduğu için bu sorunun mübhem olmadığı görüşündedir. Zira hurma nebizi ile ilgili olan konu; necaset, içmek veya başka bir şey değil, sadece onunla abdest almanın hükmüdür. Cüveynî burada örfi karinenin, tıpkı lafzî karine gibi lafzı mübhem olmaktan çıkardığını söylemiştir. ${ }^{78}$

77 Gazalî, el-Müntehal fi'l-cedel, 354-356.

78 Ayrıntılı bilgi için bk. Gazalî, el-Müntehal fi'l-cedel, 356-358. 


\section{Kendisine soru sorulandan kaynaklı hatalar:}

İlmî bir tartışmanın/araştırmanın sağlıklı biçimde ilerleyebilmesi ve sonuca ulaşabilmesi için cevapların aranacağı kaynaklar doğru olarak belirlenmelidir. Bundan hareketle ele alınan meseleyi anlayamayacak durumda olan kişilere ilgili meseleleri sormak bu noktada hata yapmak olarak görülmüştür. Mesela "ilimde en üst düzeyde olanların bile güçlükle anlayabildiği konuların, henüz eğitimin başında, anlayışı kıt kişilere sorulması" bu yanlışa örnek olarak gösterilmektedir. ${ }^{79}$

Henüz eğitimin başında olan kişilere anlayamayacağı meseleleri cevap almak amacıyla sormanın yanlış olduğu kabul edilmiştir. Fakat şüphe içerisinde olan kişilere şüphe duyduğu meseleler hakkında cevap almak amacıyla soru sormanın uygun olup olmadı̆̆ı hakkında farklı görüşler ileri sürülmüştür. Bazıları bu durumda olan kişilere "neden şüphe içerisindesin?" şeklinde soru sorulabileceğini söylemişlerse de Gazalî, tercih edilen görüşün bunlara ilgili meselelerde cevap almak amacıyla soru sorulmayacağı olduğunu ifade etmiştir. Çünkü kişi zaten şüphe içinde olduğunu itiraf etmiş, o konuyu bilmediğini açıkça beyan etmiş̧tir. Uygun olan o kişiye sorulması değil, o kişinin şüphe ettiği konuyu sormasıdır. Zira bilmeyen kişiye "neden bilmediğini" sormak çirkin bir davranıştır. ${ }^{80}$

$\mathrm{Bu}$ yaklaşımlardan hareketle henüz eğitiminin başında olan kişilere anlayamayacakları konularda soru sormanın, onlarla tartışmaya girmenin faydasız olacağı anlaşılmaktadır. Aynı şekilde ilgili meselelerde şüphe içerisinde olan kişilere de o konularda cevap almak amaciyla soru sormak yanlış bir tutum olarak görülmüştür.

\section{Anlaşılmak istenen konudan kaynaklı hatalar:}

"Doğru soruyu yanlışından ayırmak" konusundaki ilk başlıkta herkes tarafından bilinen ve çok açık olan konuların sorulmasının yanlış olduğu açıklanmış̧ı. Bunun diğer uç noktası olarak, meleklerin ayak sayıları gibi bilinmesi mümkün olmayan konularda sorular sorulması da yanlış sorular olarak değerlendirilmiştir. İlk başlıktaki abeslik; sorulan konunun açıklığından, burada ise bilinemezliğinden kaynaklanmaktadır. Bu şartları sağlayan soru sahih, sağlayamayanlar ise batıldır. ${ }^{81}$

Bu açıklamalardan hareketle ilmî tartışmaların/araştırmaların sağlıklı biçimde ilerleyebilmesi ve sonuca ulaşabilmesi için tartışılacak/araştırılacak meselenin kendisi hakkında bilgi edinilmesi mümkün olan konular arasından seçilmesi gerektiğini söylemek mümkündür.

Bu üst başlık altında ittifak edilen konularda münazara yapmak istemek de beşinci madde olarak eklenebilir. Nitekim İbn Akil, kendisine soru sorulan kişinin sadece tarafların ihtilaf ettiği mesele sorulmuşsa cevap vereceğini, tarafların ittifak ettiği meselelerde ise cedelin gerçekleşmeyeceğini, bu konularda soru sorulanın cevap verme zorunluluğunun olmadığını belirtmektedir. ${ }^{82}$

79 Gazalî bunu şöyle ifade etmektedir: Gabi kişilere İbnu'l-Haddad'ın (ö. 302/915) eserlerindeki karışık konuların sorulması gibi. Bk. Gazalî, el-Müntehal fi'l-cedel, 358.

80 Gazalî, el-Müntehal fi'l-cedel, 358-359.

81 Gazalî, el-Müntehal fi'l-cedel, 359.

82 İbn Akil, el-Vazıh fi usuli'l-fikh, I, 309. 


\section{Cevapta dikkat edilmesi gereken konular}

Cevap konusu genel olarak soru konusu ile birlikte ele alınmaktadır. Yukarıda da görüldüğü üzere, sorunun kısımları ile birlikte cedel eserlerinde cevabın da kısımlarına yer verilmiştir. Bunun haricinde cevap hakkında ele alınan birkaç başlık daha vardır. Bunlar kısaca; cevap verirken karşıdakinin mezhebini dikkate almanın gerekli olup olmaması, cevabın soru ile mutabık olması ve farz ile bina başlıklarıdır.

Gazalî cevap konusunu iki fasılda ele almıştır. İlk fasıl sahih cevap ile fasid cevabın özellikleri hakkındadır. İkinci fasılda ise soru umumi olarak sorulduğunda cevap verenin umumi bir şekilde cevap vermesi hakkındadır ki bu, farz olarak isimlendirilen konudur. Farz konusu bu çalışmada müstakil bir başlık altında ele alınacaktır.

Cevabın sahih ve fasid oluşu: Sahih cevap, sahih bir soru üzerine söylenen/verilen ve soru soranın maksadı ile örtüşen cevaptır. Fasid cevap ise fasid bir soru üzerine söylenen/verilen ve soru soranın maksadını 1skalayan (udul) cevaptır. ${ }^{83}$

İbn Akil, soru soran kişinin soruda neyi sorduğunu çok iyi tetkik etmesi ve verilen cevabın sorduğu soru ile uyuşup uyuşmadığına dikkat etmesinin gerektiğini belirtmektedir. Ona göre cedele hâkim olmayan birçok kişi, kendisine sorulan şeyden başka bir cevap vererek soruyu cevapladığını sanmaktadır. Soru soran kişi cevap verenden daha az bilgili olduğu zaman bu cevapla yetinmekte ve sorusunun cevabını aldığını sanmaktadır. İbn Akil bu konuyu bir örnekle şöyle açıklamaktadır:

"Soru soran mesela nebizin haram olup olmadığını sorar. Cevap veren de "bazı âlimler bunu
haram kabul etmişlerdir" diyerek karşılık verir. Oysaki cedel ehline göre bu, sorunun cevabı
değildir. Bu durumda soru soranın cevap vereni sıkıştırması ve "ben sana bazı âlimlerin
haram görüp görmediğini sormadım, haram olup olmadığını sordum. Bana; ya haramdır,
ya değildir ya da bilmiyorum şeklinde cevap ver" demesi gerekmektedir. Böyle sıkıştırarak
karşısındakini cevap vermeye veya bu konuda bilgisinin olmadığını açıklamaya yönlendirir."" ${ }^{4}$

Gazalî ve İbn Akil'in bu açıklamalardan hareketle bir cevabın sahih olabilmesi için; cevabın sahih bir soru karşısında ortaya konulmuş olması ve soran kişinin öğrenmek istediği meseleyi açıklamasının gerektiğini söylemek mümkündür.

Aşağıda cevap ile ilgili olan diğer konulara yer verilecektir.

\section{Cevap açısından soru soran kişinin bir görüşünün olmasının gerekip gerekmediği}

Soru soran kişi öğrenmek ve irşad edilmek istediği için sorduğu meseleye onun belirli bir fikhî görüş açısından yaklaşmaması uygun olandır. Fakat fikhî meseleler üzerinde gerçekleşen münazarada fukaha, soru soran kişinin belirli bir görüşe sahip olmasını ve o görüş penceresinden sorular sormasını kabul etmişlerdir. Zira fikhî meseleler zan üzerine kurulu olan ve birçok

83 Gazalî, el-Müntehal fi'l-cedel, 368.

84 İbn Akil, el-Vazıh fi usuli'l-fikh, I, 301. 
olasılığa açık olan bir tartışma alanıdır. Soru soranın belirli bir görüş açısından soru sorması, tartışmanın dağılmasını engeller. Ayrıca fikhî meselelerde kendisine soru sorulan (mesul) bazen kendi görüş ve amacını ancak karşısındakinin görüşünün batıl olduğunu göstererek ortaya koyabilir. Dolayısıyla fikhî meseleler üzerinde cereyan eden münazaralarda soru soran kişinin bir mezhep mensubiyeti olmazsa, tartışmanın alanı kontrol edilemeyebilir ve münazara faydasız bir hale gelebilir. Gazalî kelam alanındaki münazarada ise soru soran kişinin belirli bir mezhebe mensup olmasının gerekmediği görüşündedir. Zira kelam konularındaki soru, "niçin” sorusu ile sorulan mutalebeden ibarettir. Bu soru zinciri nihayete erdiğinde münazara da bitmiş olur. Aklî konularda (makul) soru soran kişinin belirli bir mezhebe mensup olmasının gerekli olup olmadığı konusunda da ihtilaf edilmiştir. Gazalî aklî konularda bazılarının soru soran kişinin belirli bir mezhebe mensup olmasının gerekmediğini ifade etmekte fakat kendisinin farklı görüşte olduğunu söylemektedir. Çünkü Gazalî’ye göre kişi kendi ön kabulleri ile çelişen bir soru sorduğunda o soruya cevap verilmemesi gerekmektedir. Mesela nazar yönteminin batıl olduğuna ve bu yöntemin bilgiye ulaştırmayacağına inanan bir kişi nazar üzerine kurulu bir delil sorduğunda bu soruya cevap vermeye çalışmak anlamsız olacaktır. ${ }^{85}$ Fakat Razî, kelam alanında da münazarada soru soran tarafın belirli bir mezhebe mensup olması gerektiğini ifade etmektedir. Zira Razî, Mutezile veya Dehriyye mezhebine mensup olan biriyle yapılan münazaranın/konuşmanın veya sofistlerle yapılan münazaranın birbirinden farklı olması gerekir demiştir. ${ }^{86}$

\section{Cevapta farz ve bina}

Cevap konusu ele alınırken üzerinde en fazla durulan konulardan biri, cevap esnasında farz yapmanın caiz olup olmadığı ve farz yapılması halinde bina yapmanın gerekli olup olmadığı konusudur. Bu sebeple farz ve bina konularının müstakil birer başlık altında ele alınması uygun görülmüştür.

\section{A. Farz}

Kelime olarak "kesmek ve takdir etmek" anlamına gelen farz, 1stılah olarak "kişinin kendisine yöneltilen umumi soruya, sorunun ihtiva ettiği suretlerden biri üzerinden hususi cevap vermesi veya umumi fetva/cevap verip hususi delil zikretmesi" olarak tarif edilmiştir. Mesela birden fazla sureti/tarafi ihtiva eden bir mesele sorulduğunda, cevap veren bu suretlerden tümünü değil de sadece bir veya birkaç tanesini cevaplarsa farz yapmış olur. Zira bu şekilde cevap veren kişi, kelime anlamı kesmek olan farz yaparak, cevap verdiği sureti, sorunun ihtiva ettiği diğer suretlerden keserek ayırmış olur. ${ }^{87}$ Tariften hareketle cedel eserlerinde söz edilen farzın iki kısma ayrıldığı anlaşılmaktadır: 1. Fetvada farz, 2. Delilde farz.

85 Gazalî, el-Müntehal fi'l-cedel, 360-361.

86 Gazalî, el-Müntehal fi'l-cedel, 361; Razî, el-Cedel, 138.

87 Ebu Muhammed İbnu'l-Cevzî, el-İzah fi kavanini'l-lstılah fi'l-cedel ve 'l-münazara, thk. Mahmûd Muhammed Dügeym. -(Kahire: Mektebetu Medbuli, 1995), 133; Tufî, Alemü'l-cezel fi ilmi'l-cedel, 21; Zerkeşî, el-Bahru'lmuhit fi usuli'l-fikh, VII, 441. 
1. Fetvada farz: Kişinin kendisine genel/umum olarak sorulan ve birçok sureti barındıran bir soruya, sorunun ihtiva ettiği suretlerden biri üzerinden cevap vermesidir. Mesela fasid akdin münakid olup olmadığı sorulmuş olsun. Fasid akdin; bir dirhemi iki dirhem karşılığında satmak, şarap ve domuz gibi haram bir şeyi semen olarak kullanmak, semenin meçhul olması ve vadenin meçhul olması gibi birçok sureti vardır. Cevap veren bu suretlerden sadece biri üzerinden, mesela "bir dirhemi iki dirhem karşılı̆̆ında satmak caiz değildir" şeklinde fetva verdiğinde fetvada farz yapmış olur. ${ }^{88}$

2. Delilde farz: Kişinin umumi cevap/fetva verdikten sonra hususi bir delil ortaya koymasıdır. Mesela kişinin “fasid akitlerin hükmü nedir?” sorusuna "fasid akitler münakid değildir" şeklinde cevap verdikten sonra Peygamber Efendimizin bir dirhemi iki dirhem karşılığında satışını yasaklamasını ${ }^{89}$ delil olarak zikretmesi delilde farz örneğidir. ${ }^{90}$ Yukarıda belirtildiği gibi fasid akitlerin birçok sureti vardır ve bir dirhemi iki dirhem karşılığında satmak da bu fasid akitlerin suretlerinden biridir. Kişi bu örnekte "fasid akitler münakid değildir" şeklinde umumi bir cevap vermiş olmasına rağmen delil olarak sadece fasid akitlerin suretlerinden birinin delilini zikretmek ile yetinerek delilde farz yapmıştır.

Farzın caiz olup olmadığı konusunda ihtilaf edilmiştir. Yusuf b. Abdurrahman Muhyiddin İbnu'l-Cevzî el-Hanbelî (ö. 656/1258), bu konuda şu şekilde dört farklı görüş olduğunu ifade etmektedir: 1. Farz sadece fetvada caizdir. 2. Farz sadece delilde caizdir. 3. Her ikisinde de caiz değildir. 4. Her ikisinde de caizdir. ${ }^{91}$ Razî ise bu konuda şu şekilde üç farklı görüş olduğunu söylemektedir: 1. Farz yapmak mutlak olarak caizdir. 2. Farz yapmak mutlak olarak caiz değildir. 3. Belirli koşullarla farz caizdir. ${ }^{92}$ Razî’nin verdiği taksimat esas alınarak, cedel eserlerinde açıklamalarına yer verilen ikinci ve üçüncü görüşler hakkındaki yaklaşımlar aşağıda ortaya konulmaya çalışılacaktır.

Farz mutlak olarak -fetvada da delilde de- caiz değildir görüşü: Ebubekir İbn Fürek (ö. 406/1015), fetvada da delilde de farzın caiz olmadığg görüşündedir. Çünkü ona göre soru cevaba, delil de medlule mutabık olmalıdır. Oysaki burada hususi olan (ortaya konulan delil veya cevap/fetva), umumi olana (soruya veya medlüle) mutabık değildir. ${ }^{93}$ Gazalî, İbn Fürek'in bu görüşünü şöyle açıklamıştır:

Üstad Ebubekir İbn Fürek el-Isbahanî (ö. 406/1015), farzı kabul etmemiş ve bu görüşünü şöyle açıklamıştır: Delilde farz yapma durumunda iki ihtimal vardır: 1 . Kendisine soru sorulan umumi cevap verir. Bu durumda delilin de umumi olması gerekir zira has olan delil, verilen umumi cevabın delili olamaz. 2. Kendisine soru sorulan hususi cevap verir. Bu durumda kendisine sorulan soru umumi olduğu için soruya cevap vermemiş olur. ${ }^{94}$

88 Tufî, Alemü'l-cezel fi ilmi'l-cedel, 21-22.

89 İbn Mâce, "Sarf”, 48, (2256).

90 Tufî, Alemü'l-cezel fi ilmi'l-cedel, 22.

91 İbnu'l-Cevzî, el-İzah fi kavanini'l-lstılah fi'l-cedel ve'l-münazara, 140.

92 Fahreddin er-Razî, el-Cedel, 136-137.

93 Tufî, Alemü'l-cezel fi ilmi'l-cedel, 23.

94 Gazalî, el-Müntehal fi'l-cedel, 368. 
Gazalî, İbn Fürek'in bu görüşünü verdikten sonra onun dışındaki cedel âlimlerinin cevap verenin farz yapmasının caiz olduğu konusunda icma' ettiklerini söylemektedir. ${ }^{95}$

Belirli koşullarla farz caizdir görüşü: Farz yapmanın caiz olduğu görüşünde olanların genellikle bunun için belirli koşullar getirdiği görülmektedir. Bu koşulların iki başlık altında ortaya konulduğunu söylemek mümkündür. 1. Bu görüş sahiplerine göre farz yapmak isteyen kişi, cevabının başında farz yapacağını söyleyerek farz yaparsa caizdir, fakat cevabının başında farz yapacağını belirtmemişse cevabın ilerleyen aşamalarında farz yapması caiz değildir. ${ }^{96}$ Cevap veren kişi şayet meselenin tümünü delillendireceğini söyleyerek konuşmasına başlayıp sonrasında meselenin sadece belirli yerlerini seçerse ilk baştaki söylediğinden dönmüş olacağından ve amacına ulaşmaktan aciz kaldığgndan inkitaya ${ }^{97}$ hükmedilir. ${ }^{98} 2$. Bu görüş sahiplerine göre farz yapılarak ortaya konulan delilin illeti, sorudaki suretlerden en az birini kapsamalıdır. ${ }^{99}$ Farz yapılarak ortaya konulan delil şayet sorulan meselenin suretlerinden hiçbirine ait değilse bu şekilde delilde farz yapmak caiz değildir. Konuyla ilgili olarak Şirazî ve Bacî keylî olmayan yiyecek maddelerinde ribanın cereyan edip etmediği sorusuna karşılık kişinin sadece buğday örneği üzerinden cevap vermesinin caiz olduğunu söylemektedirler. Çünkü onlara göre verilen bu örnek, sorunun ihtiva ettiği diğer suretler için de cevap teşkil etmektedir. Farzın caiz olmadığ 1 duruma ise her iki müellif kendisine su dışındaki sıvılarla abdest almanın caiz olup olmadı ̆̆ı sorulan Hanefî birinin zaferan suyu ile abdest alınmasının caiz olduğu şeklinde cevap vermesini örnek göstermektedir. Zaferan suyu Hanefî mezhebine göre su olarak kabul edildiğinden soruda belirtilen "su dışındaki sıvılar”'a karşılık gelmemektedir ve bu sebeple böyle bir cevap vererek farz yapmak caiz değildir. ${ }^{100}$

Görüldüğü üzere Şirazî ve Bacî’ye göre delilde farz yapılabilmesinin caiz olması için cevap verilen ve açıklanan suret ile sorulan diğer suretlerin aynı özelliklere sahip olması gerekmektedir. Çünkü onlar, farz yapılan suret ve delilden hareketle sorunun ihtiva ettiği diğer suretler için de aynı cevabın geçerli olduğunu kabul etmiştir. Fakat bu konuda cedel müelliflerinin hemfikir olmadıkları görülmektedir. Zira ileride görüleceği üzere bu yaklaşıma karşı çıkan cedel müelliflerine göre, bu durumda ortaya konulan delil sorunun ihtiva ettiği tüm suretler için geçerli kabul edildiğinden farz yapmış olmanın anlamı kalmamaktadır.

Razî, bu konuda ek bir açıklama yaparak farz yapılarak verilen cevap ve açıklanan suret ile sorulan sorunun suretleri örtüşmüyorsa bu durumda kişinin bina yapmasının gerekli olduğunu ifade etmiştir. Razî’ye göre bu durumda farz yapan kişinin “her iki suretteki (yani kendisinin

95 Gazalî, el-Müntehal fi'l-cedel, 368; Tufî de İbn Fürek dışındakilerin farzı caiz kabul ettiklerini ifade etmektedir. Bkz. Tufî, Alemü'l-cezel fi ilmi'l-cedel, 23.

96 Fahreddin er-Razî, el-Cedel, 136-137.

97 İnkita, cedel taraflarından birinin kendi görüşünü desteklemeyi sürdürmeyi devam ettirememesi ve amacına ulaşamadan cedeli devam ettirmekten aciz kalmasıdır. Ayrıntılı bilgi için bk. Bilik, Fıkhın Bir Alt Disiplini Olarak İlmu'l-Hilaf, 221-226.

98 Bacî, el-Minhac fi tertibi'l-hicac, 38; Şirazî, el-Mülahhas, 124-125.

99 Zerkeşî, Cüveynî'nin farz yapılarak ortaya konulan delilin, sorunun ihtiva ettiği diğer suretleri da kapsaması gerektiği görüşünde olduğunu ifade etmektedir. Bkz. Zerkeşî, el-Bahru'l-muhit fi usuli 'l-fikh, (yy: Daru'l-Kutubî, 1994/1414), VII, 443.

100 Şirazî, el-Mülahhas, 124-125; Bacî, el-Minhac fi tertibi'l-hicac, 37-38. 
farz yaptığg konu ile sorunun içerdiği konudaki) ihtilaf aynıdır" diyerek bina yapmama hakkı yoktur. ${ }^{101}$

Yusuf b. Abdurrahman Muhyiddin İbnu'l-Cevzî el-Hanbelî (ö. 656/1258), kendisine göre farzın fetvada caiz olduğunu fakat delilde caiz olmadığını belirtmektedir. Muhtemelen $\mathrm{O}$, farzın delilde caiz olmaması ile umumi cevap verildikten sonra suretlerden sadece biri hakkında delil ortaya konulmasını kast etmektedir. Nitekim İbnu'l-Cevzî'ye göre farz yapılan suretten hareketle diğer suretler de aynı hükme tabi olmuş olmaz. Ona göre bu suretler hakkında cevap veren susmuş, cevap vermemiş kabul edilmelidir. ${ }^{102}$

İlgili görüş sahipleri tarafından bu koşullar altında cevap verenin farz yapmasının kabul edilmesinin bazı faydaları olduğu ifade edilmiştir. Tufî, belirli koşullar altında farz yapılmasının kabul edilmemesi halinde şu tehlikelerin belireceğini ifade etmektedir: 1. Kişi bilmediği suretleri de kapsayacak şekilde umumi cevap vererek bilmediği halde fetva vermek durumunda olur ki bu haramdır. 2. Sorulan sorunun ihtiva ettiği bazı suretleri bilmesine rağmen hiç cevap vermeyebilir. Böyle yapması halinde bildiği suret hakkındaki bilgisini gizlemiş olur ki bu da haramdır. Tufî’ye göre bu yanlışlara düşülmemesi için farzın belirli koşullar altında kabul edilmesi gerekmektedir. Nitekim O, "bütünüyle idrak edilemeyen bütünüyle terk edilmez" ve "bazı şerler diğer bazı şerlerden ehvendir” kaidelerinin de bunu gerektirdiği görüşündedir. Bunlardan hareketle Tufî, farz yapılmasının kabul edilmesinin faydalarını şöyle açıklamaktadır:

Farz yapılarak verilen cevapta iki yönden fayda vardır: A. Cevap verenin bildiği suretin bilgisinden soru soran istifade etmiş olur. B. Cevap veren kişi, bildiği suretten hareketle umumi cevap vermediği için, içinden çıkamayacağı problemlere/işkal düşmemiş olur. Mesela kadınların kendi başlarına nikâhta taraf olup olmayacakları sorulmuş olsun. Kadının kendi başına nikâhta taraf olmasının caiz olduğu suretler de caiz olmadığı suretler de mevcuttur. Cevap veren kişi bildiği sureti genelleyerek cevap verirse, diğer hükümlerin uygulandığ 1 suretlerde verdiği cevabı kendi aleyhine kullanılır. Ayrıca sorunun içinde cevap verilen suret de ihtiva edildiğinden bütünüyle bir intibak olmasa da sorulan suretler içerisinde farz yapılarak verilen cevap yer aldığı için farz yapılarak cevap verilen suret ile sorunun ihtiva ettiği o suret arasında intibak vardır. ${ }^{103}$

Razî’ye göre farz yapılmasının kabul edilmesinin üç faydası vardır: 1. Cevap veren bazen sorunun kapsadığı tüm suretlerin cevabını bilmez. Farz yapmak caiz görülmediğinde kişi bildiğini açıklamaktan engellenmiş olur ki bu, münazara kapısının kapanmasına sebep olur. 2. Cevap veren bazen sorunun kapsadığı tüm suretleri biliyor olmasına rağmen tek bir oturumda her sureti açıklaması mümkün olmaz, diğer suretler için farklı oturumlar yapılması gerekir. Bu durumda bir oturumda genel sorulan sorunun farz yaparak bir suretini, diğer oturumlarda da diğer suretlerini açıklar. 3. Cevap veren bazen farz yaparak soru soran kişiyi en çok sıkıştıracak suret üzerinden cevap verir. ${ }^{104}$

101 Fahreddin er-Razî, el-Kaşif, 103.

102 İbnu'l-Cevzî, el-İzah fi kavanini'l-ıstılah fi'l-cedel ve'l-münazara, 141.

103 Tufî, Alemü'l-cezel fi ilmi'l-cedel, 23-24.

104 Fahreddin er-Razî, el-Cedel, 136-137. 
Bu açıklamalardan hareketle şunları söylemek mümkündür: İlmî tartışma ve araştırmalarda cevabı aranılan soru tüm muhtevası ve içerdiği farklı suretler ile belirlenmelidir. Daha sonra bulunan delil ve cevap, sorunun içerdiği suretlerden sadece birine yönelik ise öncelikle delilin ait olduğu suret ifade edilerek bu delil ve cevap ortaya konulmalıdır. Cevabı aranılan sorunun içerdiği tüm suretler hakkında bulunan delilden hareketle aceleyle genellemeye gidilmemeli, ilgili suret ile sorunun ihtiva ettiği diğer suretler arasındaki benzerlik ve farklılıklar tahlil edilmelidir. Bu aşamadan sonra uygun görülmesi halinde, gerekçelendirme yapılarak sorunun ihtiva ettiği diğer suretler delili ve cevabı bulunan suret üzerine bina edilmelidir. Böyle bir bina faaliyeti olmaksızın delili ve cevabı bulunan suretten hareketle sorunun/araştırmanın ihtiva ettiği diğer suretlerin aynı hükme/cevaba tabi olmadığı gözlerden kaçırılmamalıdır.

\section{B. Bina}

Bina, farz ile yakından ilgili bir kavramdır. ${ }^{105}$ Bu bakımdan bina, cevap verirken sorunun ihtiva ettiği suretlerden birini cevaplayarak farz yapan kişinin, sorunun ihtiva ettiği diğer suretleri verdiği cevap üzerinden açıklaması, verdiği cevap üzerine kurması anlamına gelmektedir. ${ }^{106}$ Bina'nın türleri ve gerekli olup olmadığı konusunda cedel müellifleri farklı görüşler öne sürmüşlerdir. Bina ile ilgili bu iki konu hakkında ilgili cedel eserlerinde ortaya konulan yaklaşımlar aşağıda özetlenmeye çalışılacaktır.

Bina'nın türleri: Cedel eserlerinde bina'nın farz ile ilişkisinin kurulup kurulmamasından hareketle bina'nın türleri hakkında iki farklı yaklaşım benimsendiği görülmektedir. Bina konusunu farz ile bağlantı kurmadan açıklayan müellifler, bina konusunu bir hükmün delillendirilmesi bakımından ele almaktadırlar. Buna göre sorulan meseleyi başka bir mesele üzerine kurarak açıklamak anlamına gelen bina, açıklanan meselenin bir usul meselesi üzerine kurulması veya başka bir fürû' meselesi üzerine kurulmasından ibarettir. ${ }^{107} \mathrm{Bu}$ anlamda ilmî

105 Farz ile ilişkisi dışında bina, -ileride açıklanacağı üzere- bir meselenin başka bir füru’ meselesi üzerine veya bir usul meselesi üzerine kurulması anlamında da kullanılmıştır. Burada ise bina, sadece farz ile ilişkisi dikkate alınarak açıklanmıștır.

106 Tufî, Alemü'l-cezel fi ilmi'l-cedel, 25; Zerkeşî, el-Bahru'l-muhit fi usuli'l-fikh, VII, 441-442.

107 Bacî, el-Minhac fi tertibi'l-hicac, 38; Şirazî, el-Mülahhas, 126; Zerkeşî, el-Bahru'l-muhit fi usuli'l-fikh, VII, 441-442. Örnek olarak Bacî söz konusu eserinde bu konuyu şöyle ele almaktadır: "Bina yöntemi iki kısma ayrılmaktadır: 1. Sorulan meseleyi bir usul meselesi üzerine bina etmek: Mesela Zahirî mezhebine mensup olan biri Malikî mezhebine mensup olan birine balda faiz olduğunun delilini sorduğunda Malikî mezhebine mensup olan kişi, bu görüşlerini kıyas üzerine kurduklarını söyler. Zahirî mezhebine mensup olan kişiye şayet kıyas delilini kabul ediyorsa kendisine delilini açıklayacağını, bu delili kabul etmiyorsa önce onu konuşmaları gerektiğini ifade eder. 2. Sorulan meseleyi bir fürû' meselesi üzerine bina etmek: Mesela Malikî mezhebine mensup olan birine yün ve kılın ölümle beraber necis hale gelip gelmediği sorulduğunda, Malikî mezhebine mensup olan kişi bu görüşlerini kıl ve yünde ruh/can olmadığı meselesi üzerine bina ettiklerini söyler. Soran kişiye bu görüşü kabul ediyorsa açıklamaya devam edeceğini eğer kabul etmiyorsa önce o meseleyi konuşmaları gerektiğini ifade eder. $\mathrm{Bu}$ yöntemin kabul edilebilmesi için her iki meselenin de tarikinin aynı olması gerekmektedir. Meselelerin tarikleri farklı ise bir meselenin diğer mesele üzerine bina edilmesi kabul edilmez. Mesela Hanefî mezhebine mensup olan birine Müslümanın kâfir karşılığında kısasen öldürüleceği şeklindeki görüşünü delillendirilmesi sorulmuş olsun. Hanefî mezhebine mensup olan kişi "ben bu meseleyi hür olanın köle karşılığında kısasen öldürüleceği meselesi üzerine bina ediyorum" sözü kabul edilmez. Çünkü bu iki farklı meseledir ve bu meselelerden biri, diğerinin tariki değildir, dolayısıyla bu meselelerden birinin diğeri üzerine bina edilmesi caiz değildir." 
tartışmalarda binanın geçerli olması için cevap veren kişinin cevabına başlarken bina yöntemini kullanacağını belirtmesi gerektiği ifade edilmiştir. Şayet cevabının başında bina yöntemini kullanacağını belirtmemişse, cevabını açıklayacağı meseleyi üzerine kurmak istediği diğer meselenin usul meselesi veya fürû' meselesi olmasından hareketle münazara esnasında böyle bir bina yöntemin caiz kabul edilip edilmeyeceği hususunda farklı görüşler ileri sürülmüştür. ${ }^{108}$

Bina konusunu farz ile bağlantılı olarak açıklayan cedel müellifleri ise, farz yaparak sorunun ihtiva ettiği suretlerden sadece birine cevap verip delillendiren kişinin, sorunun ihtiva ettiği diğer suretleri, açıkladığı suret üzerine kurmasını ve böylelikle onlara da cevap vermesini kast etmektedirler. Bu bakımdan bina yapmanın iki yöntemi vardır: 1. Cevap verirken farz yaparak sorunun ihtiva ettiği suretlerden sadece birine yönelik delil ortaya koyan kişi, ortaya koyduğu bu delilin sorunun ihtiva ettiği diğer suretler için de geçerli olduğunu açıklayabilir. 2. Cevap verirken farz yaparak sorunun ihtiva ettiği suretlerden sadece birine yönelik delil ve hüküm ortaya koyan kişi, aralarındaki cami' vasıftan ötürü sorunun ihtiva ettiği diğer suretlerin de aynı hükme tabi olduğunu kıyas kaidelerine uygun olarak açıklayabilir. ${ }^{109}$

Bina'nın gerekli olup olmadığı: Cevap verirken farz yapan kişinin bina yapmasının gerekli olup olmadığı konusunda, farklı ihtimallerden hareketle farklı görüşler öne sürülmüştür. Burada dikkate alınan temel ilke, soru ile cevabın uyumlu olması gerektiği ilkesidir. Bu ilkeden hareketle "farz yapılarak ortaya konulan cevabın soru ile örtüşüp örtüşmediği ve farzın faydaları" konuları tartışmaların odağında yer almaktadır. Cevap verirken farz yapan kişinin bina yapmasını gerekli görenler, soru ile cevabın örtüşmesi için bu görüşte olduklarını ifade etmişlerdir. Bu durumda bina yapılmasını gerekli görmeyenler, bina yapılmasının gerekli görülmesi halinde hem yukarıda açıklanan farzın faydalarının ıskalanacağını hem de farzı

108 Bacî’ye göre cevap verirken bina yönteminin kullanmak isteyen kişi için, cevap vermeden önce bunu belirtip belirtmemesinden hareketle iki durum söz konusudur: A. Açıklamasına başlamadan önce meselenin delillendirmesini bina üzerinden yapacağını belirtmişse bunun caiz olduğu hususunda ihtilaf yoktur. B. Delillendirmeye başlarken bina üzerinden delillendireceğini belirtmemişse: a. Ezan meselesinde Malikîlerin Medine ehlinin ameli üzerine bina etmesi gibi zahir bir usul üzerine bina edilmiş olabilir. Bu usul meselesi üzerine cevabın bina edilmesini soru soran kişi kabul edebilir veya usul meselesinin açıklanmasını isteyebilir. Konuşmanın usul meselesi üzerine nakledilmesi caizdir. Soru soran kişinin bu durumda hem usul üzerine bina edilmesini hem de konuşmanın usul meselesi üzerine intikalini kabul etmeme hakkı yoktur. b. Meseleyi fürû' meselelerinden biri üzerine bina etmek istediğinde, soru soran kişinin bunu kabul etmeyip de konuşmayı bina meselesi üzerine nakletmeyi isteme hakkının olup olmadığı hususunda farklı görüşler ileri sürülmüştür. Ebu Ali et-Taberî bunu intikal olarak görüp kabul etmemiştir. Ebu İshak eş-Şirazî ise soru soran kişinin böyle bir talepte bulunma hakkının olduğunu kabul etmiştir. Bacî de usul meselesi üzerine bina etme konusunu dikkate alarak Ebu İshak ile aynı görüşü paylaşmıştır. Ayrıntılı bilgi için bkz. Bacî, el-Minhac fi tertibi’l-hicac, 38-39.

109 Tufî, Alemü'l-cezel fi ilmi'l-cedel, 25. Tufî burada ilgili konuyu şöyle açıklamaktadır: "Mesela kişiye nikâh akdinin bedenî kusurlar sebebiyle feshedilip edilemeyeceği sorulmuş olsun. Cevap veren farz yaparak sadece baras hastalığı (bir çeşit cilt hastalığı) sebebiyle ilgili hadisi delil göstererek nikâh akdinin feshedileceğini açıklar. Daha sonra diğer bedeni kusurları bunun üzerine bina ederek: "nikâh akdinin amacının gerçekleşmesine engel olan diğer bedeni kusurlar sebebiyle de nikâh feshedilebilir" diyerek bina yapar." 
kabul ettikten sonra bina yapılmasını gerekli görmenin bir çelişki olacağını iddia etmişlerdir. ${ }^{110}$ Bu farklı yaklaşımlar, farz yapılarak verilen cevabın sorunun ihtiva ettiği suretlerden biri ile örtüşmesi durumundadır. Şayet farz yapılarak cevabı verilen suret, sorulan sorunun ihtiva ettiği suretlerden hiçbiri ile örtüşmüyorsa bu durumda cevap veren kişinin farz yaparak en azından sorunun ihtiva ettiği bir sureti açıklaması gerektiği ifade edilmiştir. ${ }^{111}$ Buna karşın cevap verenin amacı meseleyi ispat etmek değil de hasmının umumi olarak ortaya koyduğu iddiayı iptal etmek ise, umum iddiası umumun içerdiği suretlerden birinin iptal edilmesi ile iptal olduğundan, cevap verenin delilde farz yapması yeterli görülmüş, bina yapmasına gerek olmadığ1 söylenmiştir. ${ }^{112}$

\section{Sonuç}

İslam âlimleri, ilgili ayet ve rivayetlerden hareketle Müslümanların bilmedikleri konularda bilenlere sorarak danışmaları gerektiğini belirtmişlerdir. Bu yönüyle soru sormak, bilgiye erişmenin ve hakikate ulaşmanın yöntemlerinden biri olarak görülmüştür. Soru sormak ve cevap vermek, İslamî ilimlerde bir araştırma yöntemi olarak ele alınmış ve soru sorup cevap vermenin adımları, adabı ve hedefleri hassas biçimde tahlil edilip sistemleştirilmiş ve cedel eserlerinden ortaya konulmuştur. Uygulamada çoğu zaman cedel, hakikate ulaşmak için değil de karşı tarafa galip gelmek amacıyla yapılmış olsa da, cedel müellifleri eserlerinde genellikle amacın hakikati izhar etmek olması gerektiğini güçlü biçimde vurgulamışlardır. Bundan hareketle cedel eserlerinde ortaya konulan bu yöntemlerin aynı zamanda genelde İslamî ilimlere dair özelde ise İslam hukukuna dair araştırma yöntemlerini ifade ettiğini söylemek mümkündür.

Fıkıh âlimleri, mezhepler arasındaki ihtilaflı fıkhî meselelerde yaygın biçimde münazaraların gerçekleşmesi ve bu alanda eserlerin telif edilmesine paralel olarak cedel eserlerinde ortaya

110 Ayrıntılı bilgi için bkz. Tufî, Alemü'l-cezel fi ilmi'l-cedel, 25-26; Gazalî, el-Müntehal fi'l-cedel, 368-370; Fahreddin er-Razî, el-Kaşif, 103-104. Örnek olarak ilgili yerde Tufî şöyle demektedir: "Farz yapan kişinin bina yapmasının gerekli olup olmadığı hakkında ihtilaf edilmiş ve üç farklı görüş ortaya konulmuştur: 1. Soru umumi olarak sorulduğu için cevabın da umumi olması gerektiğinden farz yapan kişinin bina yapması gerekmektedir. Aynı şekilde umumi cevap/fetva verip delilde farz yapan kişi de verdiği umumi cevabı delillendirebilmesi için bina yapmalıdır. 2. İki sebepten ötürü bina gerekli değildir: A. Bina yapmak gerekli olsaydı, daha önce açıklanan farzın faydalarının bir anlamı kalmazdı. Zira sorunun tüm suretleri hakkında delil bulamayan birine bina yapmayı gerekli kılmak ya onun bilmediği halde konuşması veya gücünün/bilgisinin yetmediği bir şeyle sorumlu tutulması anlamına gelmektedir. B. Hem farzı caiz kabul edip hem binayı gerekli kabul etmek çelișkilidir. Zira farzı kabul etmek, cevap verenin sorunun ihtiva ettiği suretlerden sadece birini veya bir kaçını açıklamasını, sadece bunlara dair delil zikretmesini onaylamaktır. Bu kabulden sonra binayı gerekli görmek, kişinin ikrarından dönmesi anlamına gelmektedir. 3. Farklı farz durumlarına göre bina yapılmasının gerekli olup olmadığı konusunda iki farklı durum söz konusudur: A. Yapılan farz, şayet sorunun ihtiva ettiği suretlerden biri üzerinden yapılmışsa bina gerekli değildir. B. Yapılan farz, sorulan sorunun ihtiva etmediği suretlerden biri üzerinden yapılmışsa bina yapmak gereklidir. Zira ilk durumda sorunun ihtiva ettiği suretlerden biri cevaplanmıșken ikinci durumda verilen cevabın sorunun içeriği ile alakası yoktur ve dolayısıyla sorunun içeriği ile bina yapılarak bir şekilde bağlantı kurulması gerekmektedir."

111 Tufî, Alemü'l-cezel fi ilmi'l-cedel, 26; Fahreddin er-Razî, el-Kaşif, 103; Zerkeşî, el-Bahru'l-muhit fi usuli 'l-fikh, VII, 441.

112 Fahreddin er-Razî, el-Kaşif, 103-104. İlgili yerde Razî konuyu şöyle örneklendirmektedir: "Mesela fasid akitlerin münakid olduğu şeklindeki umumi bir iddia karşısında sadece hamr ile yapılan alış verişin münakid olmadığının ortaya konulması, umum iddiasını iptal etmeye yeterlidir." 
konulan bu yöntemi, fıkha uyarlayarak bu alanda birçok eser telif etmişlerdir. Bu eserlerde genel olarak soru sorma ve cevap verme adabi ile delilleri ortaya koyma ve bu delillere yöneltilmesi muhtemel itirazlar ve bu itirazlara nasıl karşılık verilebileceği konuları temel bölümleri oluşturmuştur.

Soru sormak ve cevap vermek, doğru bilgiye ulaşabilmek adına yapılan karşılıklı diyaloğun esası/rüknü olarak görülmüş ve bu bakış açısı ile ihtilaflı fıkıh meseleleri üzerinde gerçekleşen münazaralarda soru ve cevap, birçok açıdan tahlil edilerek sistemleştirilmiştir. F1kıh âlimleri tarafından kaleme alınan cedel eserlerinde soru ve cevap verme adabını temel olarak üç başlık altında ele almak mümkündür. İlk olarak sorulması gereken sorular arasında bir hiyerarşi kurulmuş, ilk etaptaki soru sorulmadan sonraki soruya geçilmesinin yanlış olduğu ifade edilmiştir. Aynı şekilde bu hiyerarşi cevap verme sıralamasına da uygulanmıştır. Buna göre ilk olarak soru sorulan kişinin sorulan meselede bir görüşü olup olmadığı sorulmaktadır. Sonraki aşamada soru sorulan kişinin ilgili meselede görüşünün mahiyeti sorulmaktadır. Bu etapta cevap veren kişinin görüşünün delillerini bilip bilmediği ve bu delilleri açıklamaya muktedir olup olmadığı da sorulmaktadır. Üçüncü aşamada açıklanan ve mahiyeti ortaya konulan görüşün delillerinin sorulmasına geçilmektedir. Bu noktada cevap verenin ortaya koyduğu delilinin gerçekten delil olmaya elverişli olup olmadığı da soruşturulmaktadır. Dördüncü aşamada delil ile görüş arasındaki ilişkinin (vech), delilin iddiayı nasıl ortaya koyduğunun açıklanması istenilmektedir. Son aşamada ise ortaya konulan ve iddiayı nasıl desteklediği açıklanan delile; mutalebe, itiraz ve muaraza başlıkları altında ortaya konulan muhtemel eleştiriler ve tashih/ ispat istekleri yönlendirilmektedir. Bu eleştiri noktaları, delilin dayanıklılığını test etmektedir ki bunlar (deliller ve itirazlar), cedel eserlerinin soru ve cevap adabı dışında diğer temel bölümünü oluşturmaktadır.

Soru ve cevap hiyerarşisinden sonra ikinci olarak, doğru soru ve cevabın yanlış (fasid) soru ve cevaptan nasıl ayırt edilebileceği konusu gelmektedir. Buna göre muhtemel hatalar sırasıyla; soru soran kişiden kaynaklı, sorudan kaynaklı, kendisine soru sorulan kişiden kaynaklı ve anlaşılmak istenilen konudan kaynaklı hatalar olarak belirlenip, bu başlıklar altında ortaya çıkması muhtemel hatalar ilgili eserlerde açıklanmaktadır.

Soru ve cevap adabı konusunda ele alınan bir diğer konu, cevap verirken farz ve bina yöntemlerinin kullanılmasının doğru olup olmadığıdır. Birçok sureti barındıran bir soruya, sadece sorunun ihtiva ettiği belirli suretler üzerinden cevap vermenin (fetvada farz) ve sorunun içerdiği tüm suretler için değil de sadece belirli suretler için delil sunmanın (delilde farz) doğurabileceği muhtemel sorunlar cedel eserlerinde ortaya konulmakta ve bundan hareketle farz yapmanın meşruiyeti ele alınmaktadır. Bununla bağlantılı olarak cevap verenin açıkladığı ve deliller sunduğu belirli suretler üzerinden sorunun içerdiği diğer suretleri açıklamasının (bina) gerekli olup olmadığı tartışılmaktadır.

Cedel eserlerinde ayrıntılı biçimde tahlil edilip ortaya konulduğu şekliyle soruları ortaya koymada açıklanan sıralama ve cevaplarda aranılan bu şartların sadece hasmı ilzam etme 
amacına hasredilmemesi gerekmektedir. Bu yöntemlerin hem bir meseleyi karşılıklı ele almada ve münazaralarda hem de ilmî araştırmalarda takip edilmesi gereken adımları içerdiğini söylemek mümkündür. Nitekim cedel ilminde ortaya konulan yöntemlerin farklı bir sistem dâhilinde telif edilmeye başlandığı münazara eserlerinin isminin bu yönden hareketle "araştırma ve münazara yöntemleri (adabu'l-bahs ve'l-münazara)" olarak belirlendiğini söylemek mümkündür. Dolayısıyla cedel ilminin iki yönden ihmal edilmemesi gerektiği söylenebilir: 1. Başta kelam ve fikıh olmak üzere cedel yöntemi ve kavramları kullanılarak telif edilen İslamî ilimlere ait birçok eserin daha iyi anlaşılabilmesi adına, İslamî ilimler eğitiminde mantıktan sonra cedel ilminin öğretilmesinin ihmal edilmemesi gerekmektedir. 2. Başta İslamî ilimler olmak üzere konusu uygun olan diğer ilim dallarında da bu yöntemlerin araştırma yöntemleri olarak ifade ettiği değer ve bilgiye ulaşmada başarı oranının, hem geçmişte telif edilen eserler üzerinden hem yapılacak yeni araştırma ve telifler açısından gündemde tutulması gerekmektedir.

Hakem Değerlendirmesi: Dış bağımsız.

Çıkar Çatışması: Yazar çıkar çatışması bildirmemiştir.

Finansal Destek: Yazar bu çalışma için finansal destek almadığını beyan etmiștir.

Peer-review: Externally peer-reviewed.

Conflict of Interest: The author has no conflict of interest to declare.

Grant Support: The author declared that this study has received no financial support.

\section{Kaynakça/References}

Askalanî, İbn Hacer. Fethu'l-barî şehu Sahihi'l-Buharî, Beyrut: Daru'l-Marife, 1379.

Bacî, Ebu'l-Velid. el-Minhac fi tertibi'l-hicac, thk. Abdülmecid Türki, Beyrut: Dârü'l-Garbi'l-İ́slâmî, 1987. Bağdadî, Hatib. Tarihu Bağdat, thk. Doktor Beşşar Avad, Beyrut: Daru'l-Garbi'l-İslamî, 2020/1422.

Bilik, Abdurrahim. Fikhın Bir Alt Disiplini Olarak İlmu'l-Hilaf. İstanbul: Marmara Üniversitesi, Sosyal Bilimler Enstitüsü, Doktora Tezi, 2018.

Cüveynî, el-Kafiye fi'l-cedel, thk. Fevkıyye Hüseyin Mahmûd, Kahire: İsa el-Babi el-Halebi, 1979.

Çağrıcı, Mustafa. "Zarûriyyât”, Türkiye Diyanet Vakfi İslâm Ansiklopedisi (İstanbul: TDV Yayınları, 2013), XXXXIV/146-148.

Doğan, Hüseyin. "İslam Kelamcılarına göre cedel yönteminin uygulama alanı ve pratikteki yansımaları", Kafkas Üniversitesi İlahiyat Fakültesi Dergisi, 4/7, 2017, 67-96.

Ebu Davud, Süleyman b. El-Eş'as b. İshak es-Sicistanî el-Ezdî, es-Sünen, thk. Muhammed Muhyiddin Abdulhamid, Beyrut: el-Mektebetü'l-Asriyye, (ty).

Fülusî, Mes'ud b. Musa. el-Cedel inde'l-usuliyyin beyne'n-nazariyye ve't-tatbik, Riyad: Mektebetü'r-Rüşd, 2003/1424.

Gazalî, Ebu Hamid. el-Müntehal fi'l-cedel, thk. Ali b. Abdülazîz b. Ali Umeyrini, Beyrut: Darü'l-Verrak, 2004/1424.

Gazalî, Ebu Hamid. Miyaru'l-ilim, trc. Ali Durusoy, Hasan Hacak, İstanbul: TYEKB, 2013.

İbn Akil, Ebu'l-Vefa. el-Vazıh, thk. Abdullah b. Abdülmuhsin et-Türki, Beyrut: Müessesetü'r-Risâle, 1999/1420. 
İbn Hazm, Ebu Muhammed. et-Takrib li haddi'l-mantık ve'l-medhalu ileyhi bi'l-elfazi'l-ammiyeti ve 'l-emsileti'lfikhiyye, thk. Abdülhak b. Molla et-Türkmani, Beyrut: Daru İbn Hazm, 2007/1428.

İbn Mâce, Ebû Abdillâh Muhammed b. Yezîd. es-Sünen, thk. Şuayb Arnaut, Adil Mürşid, Dımaşk: Darü’rRisaleti'l-Alemiyye, 1430/2009.

İbnu'l-Cevzî, Ebu Muhammed. el-İzah fi kavanini'l-lstılah fi'l-cedel ve'l-münazara, thk. Mahmûd Muhammed Dügeym, Kahire: Mektebetu Medbuli, 1995.

Makdisî, George. Ortaçağda Yüksek Öğretim, çev. Ali Hakan Çavuşoğlu, Tuncay Başoğlu), İstanbul: Klasik Yayınları, 2012.

Mâverdî, Ebü'l-Hasen Alî b. Muhammed b. Habîb el-Basrî. Edebü'd-dünya ve'd-din, (yy): Daru Mektebetü'lHayat, (ty).

Mavil, Hikmet Yağlı. "Ebü'l-Hasan el-Eş'arî’nin Kelam Sisteminde Bir Bilgi Kaynağı Olarak Cedel”, Kelam Araştırmaları Dergisi, 10/2, (2012), 175-186.

Meydanî, Abdurrahman. Davabitu 'l-marife, Dımaşk: Darü'l-Kalem, 2011.

Miller, Larry Benjamin. Islamic Disputation Theory: The Uses-Rules of Argument in Medieval Islam, Springer, 2019.

Münavî, Muhammed Abdurrauf. Feyzu'l-kadir şerhu'l-Camiu's-sağir, Mısır: el-Mektebetü’t-Ticariyeti'lKübra, 1356.

Özel, Ahmet. "Bacî”, Türkiye Diyanet Vakfi İslâm Ansiklopedisi (İstanbul: TDV Yayınları, 1991), IV/414-415.

Özen, Şükrü. “İlm-i Hilaf yahut Fukaha Metoduna Göre Cedel Hakkında Klasik Bir Metin: Menşeü’n-Nazara”, Makalat, 2, (1999), 171-198.

Razî, Fahreddin. el-Cedel, "Fahreddin er-Razî’nin el-Cedel Adlı Eserinin Tahkikli Neşri”, nşr./thk. Ahmet Numan Ünver, Tahkik İslami İlimler Araştırma ve Neşir Dergisi 3/2 (Aralık/December 2020): 111-159.

Razî, Fahreddin. el-Kaşif, thk. Ahmed Hicâzî es-Sekkâ, Beyrut: Dârü'l-Cil, 1992/1413.

Şirazî, Ebu İshak İbrahim b. Ali. el-Mülahhas, thk. Muhammed Yusuf Niyazî, Ümmü’l-Kura Üniversitesi, Külliyetü'ş-şeri'â, Yüksek lisans tezi, h. 1407

Şirazî, Ebu İshak İbrahim b. Ali. Tabakatu'l-fukaha, nşr. İhsan Abbas, Beyrut: Daru'r-Raidi’l-Arabî, 1970,

Tûfî, Ebü'r-Rebî‘ Necmüddîn Süleymân b. Abdilkavî b. Abdilkerîm b. Saîd el-Hanbelî. Alemü 'l-cezel fi ilmi 'lcedel, thk. Heinrich Wolfhard, Wiesbaden: Franz Steiner Verlag, 1987.

Tûfî, Ebü’r-Rebî‘ Necmüddîn Süleymân b. Abdilkavî b. Abdilkerîm b. Saîd el-Hanbelî. Şerhu Muhtarari’r $r$ Ravza, thk. Abdullah b. Abdulmuhsin et-Türkî, Beyrut: Müessestür'r-Risale, 1987.

Ünver, Ahmet Numan. "Cedelin Fıkıh İlminde Kullanımı: Kudurî ve Ebu’t-Tayyib et-Taberî Arasındaki Bir Münazara Bağlamında”, Sakarya Üniversitesi İlahiyat Fakültesi Dergisi, 21/39, (2019), 68-91.

Ünver, Ahmet Numan. Fıkıh İlminde Cedel Yönteminin Kullanımı (Ebû İshâk eş-Şî̂ầî Örneği), Ankara: Akademisyen Kitabevi, 2019.

Young, Walter Edward. The Dialectical Forge: Juridical Disputation and the Evoluatin of Islamic Law, Springer, 2017.

Zerkeşî, Bedreddin. el-Bahru'l-muhit, yy: Daru'l-Kutubî, 1994/1414. 
